\title{
Financial Impact of the Opioid Crisis on Local Government: Quantifying Costs for Litigation and Policymaking
}

\author{
Elizabeth Weeks* \& Paula Sanford**
}

\begin{abstract}
The opioid epidemic has had a significant impact on individuals and communities, including local governments responsible for serving and protecting those affected individuals. This is the first study of its kind to consider whether those local government costs are quantifiable, a question that has salience both for pending opioid litigation in federal and state courts and for local planning and budgeting decisions. This Article first provides a detailed description of the opioid litigation landscape, including the federal multidistrict litigation (MDL) in Ohio, the Native American tribes' actions, and various procedural and other hurdles that local government plaintiffs face in seeking monetary recovery in court. The Article also provides a literature review of existing studies on the financial impacts of the opioid epidemic, noting the shortcomings of those studies in regards to quantifying costs for local governments. Finally, it describes our study methodology, which involved unstructured, qualitative interviews with local government department heads and other service providers to determine the extent to which their opioid costs could be readily captured. Our findings reveal that some costs are easy to track and correlate with opioids, specifically, and we provide sample calculations for some of those; other costs are not currently tracked as opioid-specific but could be with additional effort, an effort we intend to undertake with future stages of this project; and still other costs are very hard to disaggregate or quantify, although they are very real and, often, significant.
\end{abstract}

\section{INTRODUCTION}

This Article examines the financial impact of the opioid crisis on local governments, relevant to their posture both as litigants seeking damages from opioid manufacturers, distributors, and pharmacies, ${ }^{1}$ and as stewards

\footnotetext{
* J. Alton Hosch Professor and Associate Dean for Faculty Development, University of Georgia School of Law. The authors wish to thank TJ Streipe, Russell Gabriel, Ted Baggett, Fazal Khan, Elizabeth Chamblee Burch, Hien "Grant” Doan, Kate Thorne, Cole McFerren, ... .

** Senior Public Service Associate and Public Service and Outreach Faculty, University of Georgia Carl Vinson Institute of Government

1. See, e.g., Michael Kilpatrick Morton, Making the Victim Whole Again? State and Local Governments Seek to Hold Drug Companies Accountable for Holes Left in their Communities and
} 
of public monies making informed decisions about how best to address the epidemic going forward. According to the CDC, between 1999 and 2016, more than half a million people died from drug overdose. ${ }^{2}$ On average, 130 Americans die every day from an opioid overdose. ${ }^{3}$ In 2017, President Trump officially declared the opioid problem a public health emergency. ${ }^{4}$ Former U.S. Attorney General Jeff Sessions noted the substantial burden the opioid crisis has had on federal resources, having already cost the government \$115 billion in 2017 and \$1 trillion since 2001 and predicting an additional $\$ 500$ billion in opioid-related costs over the next three years. ${ }^{5}$ In the State of Georgia, "[t]he health care costs associated with opioid misuse . . were estimated at $\$ 447$ million in 2007," and projected to increase by eighty percent since then. ${ }^{6}$ Likewise, "the cost of opioidrelated inpatient care more than doubled [between 2002 and 2012], rising to $\$ 15$ billion in 2012." 7

This Article's observations and conclusions regarding how local governments might track and address the opioid epidemic draw on the authors' local government and health care finance expertise, further informed by unstructured, qualitative interviews with local government officials and administrators for private organizations in select Georgia counties. $^{8}$ The interviews were not intended to gather statistically significant, hypothesis-driven data, or even hard numbers for the counties surveyed, but rather to reality check the authors' assumptions about the

Budgets, ABA (Sept. 27, 2018), https:/www.americanbar.org/groups/health_law/publications/ aba_health_esource/2017-2018/january2018/makingthevictim/ [https://perma.cc/7YTX-TELR].

2. Understanding the Epidemic, CTRS. FOR DisEASE CONTROL AND PREVENTION, https://www.cdc.gov/drugoverdose/epidemic/index.html [https://perma.cc/DED8-V3EC] (last updated Dec. 19, 2018).

3. Id.

4. Combatting the National Drug Demand and Opioid Crisis: Memorandum for the Heads of Exec. Dep'ts and Agencies, 82 Fed. Reg. 50,305 (Oct. 26, 2017).

5. Att'y Gen. Jeff Sessions, U.S. Dep't of Justice, Attorney General Sessions Delivers Remarks Announcing the Prescription Interdiction and Litigation Task Force (Feb. 27, 2018), https://www.justice.gov/opa/speech/attorney-general-sessions-delivers-remarks-announcingprescription-interdiction-and [https://perma.cc/C2EE-A8VB] (citing Economic Toll of Opioid Crisis in U.S. Exceeded \$1 Trillion Since 2001, ALTARUM (Feb. 13, 2018), https://altarum.org/ news/economic-toll-opioid-crisis-us-exceeded-1-trillion-2001 [https://perma.cc/F39A-SLGQ]); see also Katie Benner \& Jan Hoffman, Justice Dept. Backs High-Stakes Lawsuit Against Opioid Makers, N.Y. TiMES (Feb. 27, 2018), http://www.nytimes.com/2018/02/27/us/politics/justice-departmentopioid-lawsuit.html [https://perma.cc/LM48-9SMH].

6. Substance Abuse Research Alliance (SARA), Georgia Prevention Project, Prescription Opioids AND Heroin Epidemic in Georgia - A White Paper 7 (2017), http://www.senate.ga.gov/sro/Documents/

StudyCommRpts/OpioidsAppendix.pdf [https://perma.cc/72FV-EPCZ].

7. Id.

8. See infra Part IV. 
actual and potential financial impact of the opioid crisis on local governments and the feasibility of quantifying those impacts.

The results reveal that a relatively discrete set of opioid-related costs are fairly easy to identify and quantify, such as labor and supply costs for court administration and coroners and costs related to naloxone, an opioid antagonist. But many other opioid-related expenditures, including law enforcement, jail, and other judicial-branch services, will be more difficult for local governments to accurately and comprehensively capture unless tailored tracking tools, software, coding methodologies, or spreadsheets are employed. Finally, we note a host of costs on local communities arising out of the opioid epidemic that will be hard to quantify, such as lost productivity, quality of life, and lost economic opportunity.

The opioid multidistrict litigation (MDL), which includes numerous local government plaintiffs, was the impetus for this study, but our research has multiple aims and audiences. First, it helps inform the damages calculation in the lawsuits, which very likely will be resolved by settlement, without reaching the merits of the allegations. ${ }^{9}$ The three counties included in the study are litigants and will be called upon to provide much more detailed discovery responses than our unstructured interviews. Second, it assesses the usefulness of existing "macro" (national) studies on the financial impact of opioids for determining costs on a "micro" (local) level. Existing cost studies extrapolate health care, lost productivity, and law enforcement costs from mortality and other data, but those results are very difficult to translate to any meaningful numbers for a particular city or county. Third, it examines structural and resource limits and other obstacles that local governments face in capturing the costs from the opioid epidemic. Fourth, the study supports local governments' informed decisionmaking regarding resource allocation and strategies to address the opioid crisis in the future.

This Article proceeds as follows: Part II provides background on the opioids lawsuits and need for this cost study. Part III describes existing studies of the opioid epidemic's financial impact and notes the limits of those studies to address the question presented here. Part IV describes the study methodology and findings. Part V concludes, assessing the study's implications and describing the authors' workplan for assisting local governments address the identified challenges.

9. See, e.g., Amanda Bronstad, Litigation No Substitute for Settlement, Says Opioid MDL Judge, NAT'L L.J. (May 10, 2018, 2:18 PM), https://www.law.com/national lawjournal/2018/05/10/litigation-no-substitute-for-settlement-says-opioid-mdl-judge/?slreturn=2018 0916131359 . 


\section{BACKGROUND}

This Part describes the litigation that provoked this study of costs that local governments may be experiencing due to the opioid epidemic in their communities. As noted above, this study is not aimed exclusively at the legal damages question but takes a broader and longer-range view, relevant for city and county budget and planning purposes. Nevertheless, it is helpful to understand the legal landscape, including prior rounds of opioid litigation; parties to the present actions; theories of recovery alleged; defenses asserted; damages sought; procedural developments, especially the consolidation of the cases at least for pretrial purposed in a federal MDL; parallel actions, most notably the Native American tribes' actions; and the progress of these cases toward trial or settlement.

\section{A. Opioid Lawsuits}

Amid myriad strategies to address the opioid crisis in the United States, the massive MDL in the Northern District of Ohio figures prominently. ${ }^{10}$ A number of cities, counties, townships, fire districts, tribal governments, third-party payors, health care providers, individuals, and states have filed lawsuits against prescription drug manufacturers, distributors, pharmacies, pharmacy benefit managers, as well as some nonprofit organizations, individual experts, and family owners of pharmaceutical companies. ${ }^{11}$

\section{Allegations and Responses}

Defendants include pharmaceutical giants such as Johnson \& Johnson and Purdue Pharma, large distributors such as McKesson and Cardinal Health, pharmacy chains such as CVS, Rite Aid, and Walgreens, and physicians who prescribe the drugs. ${ }^{12}$ The local government plaintiffs' complaints are fairly similar, including claims for public nuisance, violations of Racketeer Influenced and Corrupt Organizations Act (RICO), ${ }^{13}$ negligence per se, and negligence and negligent

10. In re Nat'l Prescription Opiate Litig., No. 17-2804 (N.D. Ohio 2017); Jan Hoffman, Can this Judge Solve the Opioid Crisis?, N.Y. Times (Mar. 5, 2018), http://www.nytimes.com/ 2018/03/05/health/opioid-crisis-judge-lawsuits.html [https://perma.cc/RM64-8EHT].

11. Abbe R. Gluck et al., Civil Litigation and the Opioid Epidemic: The Role of Courts in a National Health Crisis, 46 J.L. MED. \& ETHICs 351, 354-57 (2018); Erich Eiselt, Too Much of a Bad Thing: Municipalities and the Opioid Curse, 59 Mun. Law. 6, 10-11 (2018).

12. Gluck et al., supra note 11 , at 355-56.

13. 18 U.S.C. $§ 1961$ (2012 \& Supp. 2017). 
misrepresentation. ${ }^{14}$ The complaints further assert claims of fraud and fraudulent misrepresentation, false advertising, or violation of legal duties owed to the plaintiffs under state and federal statutes. ${ }^{15}$ The public nuisance claim-" "anything that interferes with rights that are held in common by the general public including public health and safety" - tracks one of the key claims by states against tobacco companies in the 1990 s. $^{16}$

The plaintiffs allege that pharmaceutical manufacturers downplayed the addictiveness of the drugs, ${ }^{17}$ and engaged in misleading and "aggressive marketing tactics, quotas for representatives, and financial kickbacks for doctors" to promote the painkillers. ${ }^{18}$ Specifically, the plaintiffs allege that the manufacturers "pushed highly addictive, dangerous opioids, falsely representing to doctors that patients would only rarely succumb to drug addiction" persuaded doctors to prescribe... opioids, which turned patients into drug addicts for their own corporate profit." 19 The allegations against pharmacies and distributors are for breach of their legal duties under federal and state law to monitor, detect, investigate, refuse, and report suspicious orders that may indicate that the drugs were being abused, essentially acting as an accessory to the crime. ${ }^{20}$ Moreover, government plaintiffs at the city, county, and state levels also attribute opioid use as the cause of negative effects on public health and safety. ${ }^{21}$ These include costs for "providing treatment for overdoses, counseling and rehabilitation services, ... costs associated with providing care for children whose parents suffer from opioid-related disability," increases in drug-related crimes like theft and assault, and increase in costs of law enforcement and other public services. ${ }^{22}$ Finally, claims against doctors revolve around unnecessary prescriptions, when the pain could have been managed in other ways, or unnecessary refills. ${ }^{23}$

14. See Complaint and Demand for Jury Trial, Augusta Cnty. v. Amerisourcebergen Drug Corp., No. 1:18-cv-00029 (S.D. Ga. Feb. 13, 2018), ECF No. 1 [hereinafter Augusta Complaint]; Complaint and Demand for Jury Trial, Jackson Cnty. v. Amerisourcebergen Drug Corp., No. 1:18-op-45581 (N.D. Ohio May 15, 2018), ECF No. 1; Complaint and Demand for Jury Trial, Crisp Cnty. v. Amerisourcebergen Drug Corp., No. 1:18-cv-00036 (M.D. Ga. Feb. 14, 2018), ECF No. 1.

15. See complaints cited supra note 14 .

16. Gluck et al., supra note 11 , at 355 .

17. Benner \& Hoffman, supra note 5.

18. Why Does Class-Action Defense Spending Continue to Rise?, EsQuire (May 10, 2018), https://www.esquiresolutions.com/why-does-class-action-defense-spending-continue-to-rise/ [https://perma.cc/YH3F-ZQTH] .

19. Augusta Complaint, supra note 14, at 2.

20. E.g., id. at 65-66.

21. Augusta Complaint, supra note 14, at 3.

22. Id.

23. See Gluck et al., supra note 11, at 354 . 
Plaintiff lawyers also have filed lawsuits on behalf of infants with an addiction-related syndrome. ${ }^{24}$ Those attorneys have sought to separate their claims from the MDL, arguing that their claims involve distinct issues and call for faster resolution, so that the affected babies can receive financial support for the services that they will require. ${ }^{25}$

Responding to the claims, drug companies have acknowledged the public health crisis but denied liability and sought dismissal of the lawsuits. ${ }^{26}$ For instance, the defendants argued that the "[r]acketeering claims should be dismissed because injury to business or property was not alleged," and public nuisance claims did not allege a "public right with which distributors interfered." 27 The manufacturers also argued that they have "extensively disclosed the risks ... and that the [FDA] approved the drugs' marketing," 28 which may raise the potential issue of federal preemption. ${ }^{29}$ Distributors asserted that they "neither market[ed] nor prescribe[d] opioids," and the alleged misconduct of failing to monitor and report suspicious orders was "too indirect" to support a claim. ${ }^{30}$ Moreover, distributors also contended that emphasis should not be placed on the aggregate number of prescriptions distributed by all distributors, since each of them "are not aware of the amounts of drugs shipped by their competitors... and therefore aggregate data cannot constitute a 'red flag." 31 Physicians can be expected to defend the allegations by asserting that their prescribing was within the standard of care and that they gave appropriate warnings to patients.

\section{Multidistrict Litigation}

As of December 2017, over two hundred prescription opioid cases had been filed in federal courts across the country. ${ }^{32}$ As of February 2018,

24. John O'Brien, Blame the Criminals, Pharmacies Facing Opioid Lawsuits Say, ForBes (June 7, 2018, 1:22 PM), http://www.forbes.com/sites/legalnewsline/2018/06/07/lets-blame-the-criminalspharmacies-facing-opioid-litigation-say/\#265045ba64b8 [https://perma.cc/5EZR-TA9U].

25. Associated Press, Babies Born in Withdrawal New Complication in Opioid Cases, VOA (Nov. 29, 2018, 3:40 PM), https://www.voanews.com/a/babies-born-in-withdrawal-newcomplication-in-opioid-cases/4680172.html [https://perma.cc/8WDP-HW8F].

26. See O'Brien, supra note 24.

27. Id.

28. Andrew Harris et al., Justice for Opioid Communities Means Massive Payday for Their Lawyers, BLOOMBERG (July 25, 2018), https://www.bloomberg.com/graphics/2018-opioidlawsuits/?srnd=prognosis.

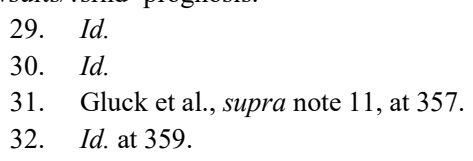


cities, counties, and Native American tribes nationwide filed more than four hundred complaints. ${ }^{33}$ As of June 2018, the number rose to more than seven hundred. ${ }^{34}$ In December 2017, over two hundred prescription opioid cases filed in federal courts across the country were consolidated in the federal MDL. ${ }^{35}$ MDL is a device under federal law that allows "civil actions involving one or more common questions of fact... pending in different districts" ${ }^{36}$ to be consolidated for more efficient pretrial handling, including discovery. ${ }^{37}$ The federal judicial panel on MDL decides whether the cases should be consolidated and, if so, to which court the cases should be transferred. MDL is distinct from federal class action in that "[a] case proceeds as a class action only if its proponents show that the claims meet the requirements of commonality, typicality, adequacy of representation, and - for money damages class actions under [Federal Rule of Civil Procedure] 23(b)(3) - predominance of common issues over individual issues."38 MDL does not join parties for common or representative litigation but may have the effect of facilitating collective resolution of the claims. $^{39}$ There is debate over the relative merits of MDL versus class action from efficiency and fairness perspectives, ${ }^{40}$ and even greater concern about forcing the parties into a mandatory class action, a step that some have speculated that Judge Polster would pursue. ${ }^{41}$

The state and local government plaintiffs, for their part, urged the federal opioids MDL, asserting that their contention against opioid manufacturers and distributors regarding breach of their duty to monitor, detect, investigate, refuse, and report suspicious orders of prescription

\footnotetext{
33. Benner \& Hoffman, supra note 5.

34. Gluck et al., supra note 11, at 351-52, 355.

35. In re Nat'l Prescription Opiate Litig., 290 F. Supp. 3d 1375 (U.S. Jud. Pan. Mult. Lit. 2017); see also Hoffman, supra note 10.

36. 28 U.S.C. $\S 1407$ (a) (2012).

37. Lexecon Inc. v. Milberg Weiss Bershad Hynes \& Lerach, 523 U.S. 26, 39-40 (1998) (pointing to legislative history indicating that the statute applies only to pretrial stages); see Elizabeth Chamblee Burch, Monopolies in Multidistrict Litigation, 70 VAND. L. REV. 67, 72 n.13 (2017). As a reality, however, cases rarely are returned to their original jurisdictions.

38. Howard M. Erichson, What MDL and Class Actions Have in Common, 70 VAND. L. REV. EN BANC 29, 37 \& n.34 (2017) (first citing FED. R. CIV. P. 23(a)(2)-(4), 23(b)(3); then citing WalMart Stores, Inc. v. Dukes, 564 U.S. 338 (2011); and then citing Amchem Prods. v. Windsor, 521 U.S. 591 (1997)).

39. Id. at 38 .

40. Compare Burch, supra note 37, with Erichson, supra note 38, at 30 (summarizing Burch's arguments).

41. E.g., Daniel Fisher, Opioid Lawyers Say Settlement May Hinge on Forcing Plaintiffs into Class Action, FORBES (Sept. 27, 2018, 6:00 AM), https://www.forbes.com/sites/legalnewsline/ 2018/09/27/opioid-lawyers-say-settlement-may-hinge-on-forcing-plaintiffs-into-class-action/\#2bde0 4451d1c [https://perma.cc/23FW-GGLN].
} 
opiates presents a common question of fact, thus meeting one of the requirements for creating an MDL. ${ }^{42}$ Judge Polster was selected to preside because of his depth of experience in MDL cases, Ohio's extensive impact from the opioid crisis, and the court's proximity to a number of defendants. ${ }^{43}$ Ohio, like West Virginia, Pennsylvania, New Hampshire, and the District of Columbia, is Ground Zero for the opioid crisis. ${ }^{44}$ In some of these communities manufacturers shipped as many as ten thousand pills per day to a single pharmacy, ${ }^{45}$ many prescribed through "pill mills" and diverted to other users through illicit sales.

As of March 2018, at least twelve counties in Georgia had filed lawsuits against opioid manufacturers and distributors. ${ }^{46}$ Those cases were quickly pulled into the MDL. The number of Georgia counties, cities, and hospital authorities filing opioids lawsuits rose to forty as of May 2018, ${ }^{47}$ and to nearly seventy (out of 159 counties) as of August 17, 2018. ${ }^{48}$ The claims in the Georgia lawsuits closely track the allegations listed above. With respect to damages, the Georgia complaints seek recovery for:

(1) costs for providing medical care, additional therapeutic, and prescription drug purchases, and other treatments for patients suffering from opioid-related addiction or disease, including overdoses and deaths;

(2) costs for providing treatment, counseling, and rehabilitation services;

(3) costs for providing treatment of infants born with opioid-related medical conditions;

(4) costs associated with law enforcement and public safety relating to

42. Courtney Hessler, Consolidation of 66 Opioid Suits Requested, Herald DisPatch (Oct. 5, 2017), http://www.herald-dispatch.com/news/consolidation-of-opioid-suits-requested/article_9c4df 826-c6a6-58fd-9ba8-ac6058aaf2ad.html [https://perma.cc/7ZH3-KVXL].

43. Id.

44. Drug Overdose Deaths, Centers for Disease Control and Prevention (Dec. 19, 2018), https://www.cdc.gov/drugoverdose/data/statedeaths.html [https://perma.cc/XD77-UU3K] (stating that in 2017 Ohio had the second highest rates of overdoses deaths per 100,000).

45. See Eiselt, supra note 11; H. Energy \& Commerce Comm., Red Flags and Warning Signs Ignored: Opioid Distribution and Enforcement Concerns in West Virginia, H. Energy \& Commerce Comm. 115th Cong. 225 (Dec. 18, 2018).

46. Nick Bowman, Hall Among 12 Georgia Counties Suing Opioid Manufacturers, GAINESVILlE TiMES (Mar. 16, 2018, 8:36 AM), https://www.gainesvilletimes.com/news/hall-among12-georgia-counties-filing-suit-against-opioid-manufacturers/ [https://perma.cc/783U-TFR9].

47. Toombs County Files Lawsuit Against Opioid Manufacturers and Distributors, SE. GA. TODAY (May 15, 2018), http://southeastgeorgiatoday.com/index.php/archived-newsbreaks/73351opioid-lawsuit-filed [https://perma.cc/Q4FK-A7GQ].

48. Jeremy Redmon, Atlanta-area Governments Sue Opioid Industry Amid Deadly Epidemic, AtLANTA J. CONST. (Aug. 17, 2018), https://www.ajc.com/news/state-regional-govtpolitics/atlanta-area-governments-sue-opioid-industry-amid-deadly-epidemic/7gtOHvSktNOI4hjoSu 9njI/ [https://perma.cc/NC4Y-8FZ5]. 
the opioid epidemic; and

(5) costs associated with providing care for children whose parents suffer from opioid-related disability or incapacitation. ${ }^{49}$

As explained further below, only a fraction of these costs are truly local - as opposed to state, federal, or private - and, even among those costs that actually fall on city and county governments, the costs are very difficult to capture as related to opioids, specifically, as opposed to other multi-drug use or other conflating factors. In addition, there are a host of other costs for local governments not alleged in the list above. Those, too, however, may be difficult to quantify.

\section{Local Government Litigants}

It bears emphasis that the posture of the lawsuits, with local governmental units as plaintiffs, is somewhat unusual. First, why not individual patients or their surviving family members, as in other pharmaceutical products liability cases? ${ }^{50}$ Second, why not states, as in the tobacco litigation in the 1990s? ${ }^{51}$ Regarding the first question, some answers can be gleaned from the first wave of opioid litigation in the early 2000s, against Purdue Pharma regarding OxyContin. ${ }^{52}$ Those cases were brought by individuals, as well as states' attorneys general, regarding the highly lucrative, extended release drug, which was marketed as being less addictive because the timed release that purportedly did not produce the same "highs" as earlier products. ${ }^{53}$ The plaintiffs in that waive of litigation alleged a "wide array of legal theories, including strict products liability, fraud, negligence, breach of implied warranty, conspiracy, and violations of state consumer protection statutes." 54 Purdue defended those lawsuits aggressively and, for the most part, successfully. Purdue asserted several arguments that tripped up the plaintiffs, including blaming the plaintiffs themselves for abusing the products and thus coming to the court with

49. See Augusta Complaint, supra note 14, at 3 .

50. See, e.g., Young K. Lee, Beyond Gatekeeping: Class Certification, Judicial Oversight, and the Promotion of Scientific Research in "Immature" Pharmaceutical Torts, 105 CoLUM. L. REV. 1905, 1911-15 (cataloguing various pharmaceutical torts cases, including class actions).

51. Master Settlement Agreement, PuB. HeALTh L. CTR., http://publichealthlawcenter.org/ topics/tobacco-control/tobacco-control-litigation/master-settlement-agreement [https://perma.cc/ T45E-3XNZ] (last visited Apr. 8, 2019).

52. See Gluck et al., supra note 11, at 353 .

53. Id.

54. Id. 
unclean hands; ${ }^{55}$ contributory negligence, again regarding the plaintiffs' own behaviors and fault; ${ }^{56}$ and intervening causes, including both the patients' and prescribing physicians' conduct, under the learned intermediary doctrine, ${ }^{57}$ which provides that the manufacturer's duty to warn is satisfied if conveyed to the prescribing physician, even if not to the patient. ${ }^{58}$ Suits by local government units avoid some of those individual facts, which raise causation and fault-based obstacles to recovery.

Although Purdue Pharma successfully defended against civil liability in the OxyContin lawsuits, it did face criminal liability in 2002. The U.S. Attorney for the Western District of Virginia launched a criminal investigation against Purdue alleging misbranding of OxyContin as difficult to abuse, less addictive, and providing "fewer peaks and valleys" than other opioids. ${ }^{59}$ Ultimately, Purdue pleaded guilty to those charges, ${ }^{60}$ and three Purdue executives were barred "for 20 years from doing business with Medicare or other taxpayer-financed health care program." 61 Purdue paid "more than $\$ 600$ million to federal and state agencies." 62

With respect to the second question, cities and counties may have stepped up as plaintiffs precisely to avoid the outcome of the tobacco litigation. That case concluded in 1998 with a Master Settlement Agreement (MSA) among "46 states, five U.S. territories, and the District of Columbia against the five largest cigarette manufacturers in America concerning the advertising, marketing and promotion of cigarettes." 63 The MSA represented the largest civil settlement to date, awarding \$206 billion to the states over twenty-five years. ${ }^{64}$ As Professor Micah Berman

\footnotetext{
55. $\quad I d$.

56. Id. at 358 .

57. Id. at 353 .

58. Restatement (ThiRd) OF TORTs: Prod. Liab. § 6(d)(1) (AM. LAW InST. 1998).

59. Press Release, FDA, FDA Announces Results of Investigation into Illegal Promotion of OxyContin by the Purdue Frederick Company, Inc. (May 10, 2007, revised May 14, 2007) available at https://web.archive.org/web/20080221180830/http://www.fda.gov/bbs/topics/NEWS/2007/NEW 01632.html.

60. Edgar Aliferov, Note, The Role of Direct-Injury Government-Entity Lawsuits in the Opioid Litigation, 87 FORDHAM L. REV. 1141, 1151 (2018).

61. Barry Meier, Ruling Is Upheld Against Executives Tied to Oxycontin, N.Y. TIMES (Dec. 15, 2010), https://www.nytimes.com/2010/12/16/business/16purdue.html [https://perma.cc/6MG5DT5L].

62. Paul D. Frederickson, Criminal Marketing: Corporate and Managerial Liability in the Prescription Drug Industry, 22 MIDWEST L.J. 115, 115 (2008).

63. Master Settlement Agreement, supra note 51.

64. Bruce Yandle et al., Bootleggers, Baptists \& Televangelists: Regulating Tobacco by Litigation, 2008 U. ILL. L. ReV. 1225, 1227, 1270 (2008); see Margaret A. Little, A Most Dangerous Indiscretion: The Legal, Economic, and Political Legacy of the Governments' Tobacco Litigation, 33
} 
explains more thoroughly in his article on this issue, nothing in the MSA expressly required states to spend those settlement dollars on public health, and states have, and continue to, put those funds toward a variety of purposes, plowing much of it into state general revenues and chipping away at tobacco-related trust funds to balance state budgets. ${ }^{65}$ Seeking to avoid a similar outcome of settlement dollars failing to reach the communities actually impacted by the opioid crisis, local governments may be eager to step up as plaintiffs this time around, thus ensuring that any funds come directly to their affected communities. ${ }^{66}$

\section{Comparing Forums}

While those points may explain why local governments figure prominently as litigants in the opioid lawsuits, they do not explain why those plaintiffs appear to welcome the MDL. The defendants are facing parallel litigation in state courts from a variety of plaintiffs. The defendants and at least some of the plaintiffs, however, seem to prefer the MDL. Some state lawsuits are brought by consumers as state class actions, claiming "higher [insurance] premiums, deductibles, and co-payments []because of effects attributable to the opioid epidemic." ${ }^{\prime 27}$ In addition, attorneys general in six states-Texas, Florida, Nevada, North Carolina, North Dakota, and Tennessee-filed lawsuits against Purdue Pharma in state courts for violation of their respective states' Deceptive Trade Practice Acts. ${ }^{68}$ After holding back for several months and through the November 2018 midterm elections, Georgia's Attorney General filed the state's opioid lawsuit in Gwinnett County Superior Court in January

CONN. L. REV. 1143, 1143 (2001).

65. See generally Micah Berman, Using Opioid Settlement Proceeds for Public Health: Lessons from the Tobacco Experience, 67 U. KAN. L. REV. 1029 (2019) (comparing issues with the tobacco MSA with a potential opioid litigation settlement); see also TOBACCO FrEE KIDS, BROKEN PROMISES TO OUR ChiLdREN: A STATE-BY-STATE LOOK AT THE 1998 TOBACCO SETTLEMENT 20 YEARs Later 1 (2018), https://www.tobaccofreekids.org/what-we-do/us/statereport [https://perma.cc/665TWVM4] ("In the current budget year, Fiscal Year 2019, the states will collect $\$ 27.3$ billion from the settlement and taxes. But they will spend only 2.4 percent of it $-\$ 655$ million - on programs to prevent kids from smoking and help smokers quit.").

66. See Gluck et al., supra note 11, at 355 .

67. Mark A. York, New York And Other State Court Opioid Litigation Moves Forward Along With Federal Opiate $R x$ MDL 2804, MASS TORT NEXUS (June 11, 2018), http://www.masstortnexus.com/mass-torts-news/new-york-and-other-state-court-opioid-litigationmoves-forward-along-with-federal-opiate-rx-mdl-2804/ [https://perma.cc/HB7P-AZH9].

68. John C. Moritz, 6 States Sue Maker of OxyContin as They Battle Expenses, Human Costs of Opioid Crisis, USA TODAY (May 16, 2018, 8:37 AM), https://www.usatoday.com/story/news/nationnow/2018/05/15/six-attorney-generals-opioid-lawsuits/612721002/ [https://perma.cc/EL7V-SN2C]. 
$2019 .{ }^{69}$

One state, West Virginia, sued a different defendant from the opioid manufacturers, distributors, and pharmacies. On November 2, 2017, the state filed a federal court lawsuit against the Joint Commission on Accreditation of Health Care Organization ("The Joint Commission"), blaming the Commission's standards for contributing to the epidemic. ${ }^{70}$ The Joint Commission is a non-profit organization that certifies 21,000 health care organizations nationwide and sets standards for those organizations to adhere. ${ }^{71}$ West Virginia alleged that The Joint Commission colluded with Purdue Pharma in producing its Pain Management Standards, ${ }^{72}$ which are viewed as largely responsible for "bringing questions about pain into every routine patient encounter," and, moreover, that Purdue and other companies funded the report. ${ }^{73}$

Although some states have filed in federal courts, ${ }^{74}$ by and large state attorneys general seem to be electing state courts, keeping the cases local and close to their constituents where any positive resolution will have maximum political impact. Moreover, U.S. Supreme Court precedent clarifies that states suing in their parens patriae powers cannot be removed to federal court on personal jurisdiction grounds. ${ }^{75}$ Recognizing that, the opioid defendants have asserted that the claims necessarily involve federal questions under the Controlled Substances Act (CSA) and Food and Drug Administration (FDA) statutes, thus requiring removal. ${ }^{76}$

In general, large defendants tend to prefer consolidation and often remove state cases to federal courts so that "there is a single legal

69. Press Release, OfFICE OF THE ATT'Y Gen. Chris CARR, Carr Announces Lawsuit Against Opioid Manufacturers and Distributors (Jan. 3, 2019), https://law.georgia.gov/press-releases/201901-03/carr-announces-lawsuit-against-opioid-manufacturers-and-distributors [https://perma.cc/ADG8-832W].

70. See Complaint, City of Charleston v. Joint Comm'n on Accreditation of Health Care Orgs., No. 17-4267 (S.D.W.Va. 2017), ECF No. 1.

71. About the Joint Commission, THE JoINT COMMISSION, https://www.jointcommission.org/ about_us/about_the_joint_commission_main.aspx [https://perma.cc/E9FQ-4KVG] (last visited Apr. $172019)$.

72. David W. Baker, The Joint Commission's Pain Standards: Origins and Evolution, THE JoINT COMMISSION (2017), https://www.jointcommission.org/assets/1/6/Pain Std History Web_Version_05122017.pdf [https://perma.cc/HSB9-2Q7Q].

73. See Gluck et al., supra note 11, at 356-57.

74. Id. at 351-53.

75. Mississippi ex rel. Hood v. AU Optronics Corp., 571 U.S. 161, 176 (2014) (holding that a suit by the State of Mississippi, as the sole plaintiff, was not a removable "mass action" for purposes of the Class Action Fairness Act).

76. See Complaint at 164, Unified Gov't of Athens-Clark County v. Amerisourcebergen Drug Corp., No. 3:18-cv-00015 (M.D. Ga. Feb. 7, 2018) (alleging negligence per se based on duties flowing from the Controlled Substances Act); see also Gluck et al., supra note 11, at 359 (discussing cases where defendants requested removal based on underlying federal issues). 
battlefield, and they are not subject to the vagaries of state-court juries across the country." "77 For perhaps the same reasons, states and other plaintiffs have resisted being pulled into federal MDL for "fear of losing leverage amid such a large number of cases."78 They may expect "better results with focused lawsuits in state court" against one or two defendants, where "many states already have won large settlements from other drug manufacturers with deceptive marketing claims."79 Thus, a local venue may be preferable. As of August 2018, Alabama was the only state to join the MDL. ${ }^{80}$

That said, states, as well as the federal government, seem to recognize the momentum building behind Judge Polster's push for settlement at the MDL. In February 2018, the U.S. Department of Justice filed a statement of interest ${ }^{81}$ in the federal lawsuits, emphasizing the government's "substantial costs and significant interest in addressing the opioid epidemic." 82 In August 2018, thirty-four states and the District of Columbia filed amicus briefs in the Ohio MDL, emphasizing the states' "unique role" in protecting its citizens' interests. ${ }^{83}$ In both instances, the federal and state governments want to make sure they have a seat at the table should discussions on how to slice the settlement pie get underway.

Local governments, by contrast, seem much more willing, and even anxious, to join the MDL. One reason may be choice of law, in particular, avoiding unfavorable state law. One notable doctrine is the municipal cost recovery rule, ${ }^{84}$ or, as it is called in Georgia, the free public services

77. Ty E. Howard \& Scarlett Singleton Nokes, 'Opioids and Legal Enforcement-A Primer', BRADLEY (July 17, 2018), https://www.bradley.com/insights/publications/2018/07/opioids-and-legalenforcement-a-primer.

78. Id.

79. Daniel Fisher, Latest Wave of State Opioid Lawsuits Shows Diverging Strategies and Lawyer Pay Scales, ForBes (May 29, 2018, 05:34 AM), https://www.forbes.com/ sites/legalnewsline/2018/05/29/latest-wave-of-state-opioid-lawsuits-shows-diverging-strategies-andlawyer-pay-scales/\#43133e166d1d [https://perma.cc/8ZCD-M9YL].

80. Amanda Bronstad, 35 AGs File Amicus Briefs Citing a State's 'Unique Role' in Fixing the Opioid Crisis, NAT'L L. J. (Aug. 15, 2018, 7:17 PM), https://www.law.com/national lawjournal/2018/08/15/35-ags-file-amicus-briefs-citing-a-states-unique-role-in-fixing-the-opioidcrisis/ [https://web.archive.org/web/20180817120437/https://www.law.com/nationallawjournal/ 2018/08/15/35-ags-file-amicus-briefs-citing-a-states-unique-role-in-fixing-the-opioid-crisis/].

81. Statement of Interest, In re Nat'l Prescription Opiate Litig., No. 17-2804 (N.D. Ohio 2017), ECF No. 161.

82. Id. at 1 .

83. Brief for the States of Arizona et. al, as Amicus Curiae in Support of the State of Alabama's Opposition to the Manufacturer Defendants' Joint Motion to Dismiss the First Amended Complaint at 1, In re Nat'l Prescription Opiate Litig., No. 17-2804 (N.D. Ohio 2017), ECF No. 874.

84. E.g., City of Philadelphia v. Beretta U.S.A., Corp., 126 F. Supp. 2 d 882, 894-95 (E.D. Pa. 2000), aff'd, 277 F.3d 415 (3d Cir. 2002) (holding that, under the doctrine, city and organizational plaintiffs could not bring an action against gun manufacturers, claiming that the gun industry's 
doctrine. ${ }^{85}$ The doctrine essentially provides that local governments cannot recover tort damages for public services that they are supposed to be providing anyway, such as fire and police protection. ${ }^{86}$ State laws vary on the strength of the doctrine, but the MDL may be a way for city and county plaintiffs to access a more favorable version of the law or avoid it altogether.

The doctrine has been used by courts to determine when government entities can recover damages from tortfeasors. Under the doctrine, "[t]he general rule is that public expenditures made in the performance of governmental functions are not recoverable." ${ }^{87}$ For example, courts have held that governments cannot recover damages for cleaning up negligently caused oil spills, ${ }^{88}$ incarceration of criminals, ${ }^{89}$ recapturing an escaped convict, ${ }^{90}$ providing health care and lost wages to a soldier injured by a private corporation, ${ }^{91}$ and industrial fire suppression. ${ }^{92}$ The doctrine has been adopted in several states, including Georgia, ${ }^{93}$ and it has been embraced by federal courts. ${ }^{94}$

The United States Court of Appeals for the Seventh Circuit's 1992 case In re Oil Spill by the AMOCO Cadiz coined the term "free public services doctrine." 95 But precedents as far back as 1903 historically rejected government claims for specific types of expenditures. ${ }^{96}$ Two 1974 Wisconsin cases $^{97}$ and one 1976 New Jersey case ${ }^{98}$ squarely recognized the modern doctrine, which has also been applied in federal court. For example, in District of Columbia v. Air Florida, Inc., the

\footnotetext{
methods for distributing guns were negligent and a public nuisance).

85. See infra notes 106-115.

86. City of Philadelphia, 126 F. Supp. 2d at 894-95.

87. Koch v. Consol. Edison Co., 468 N.E.2d 1, 7-8 (N.Y. 1984) (denying New York City's ability to recover costs "incurred for wages, salaries, overtime and other benefits of police, fire, sanitation and hospital personnel from whom services ... were required" in response to rioting that took place during a blackout caused by the power company's gross negligence).

88. In re Oil Spill by the Amoco Cadiz, 954 F.2d 1279, 1310 (7th Cir. 1992).

89. Napa State Hosp. v. Yuba Cty., 71 P. 450, 452 (Cal. 1903).

90. State Highway \& Pub. Works Comm'n v. Cobb, 2 S.E.2d 565, 566-67 (N.C. 1939).

91. United States v. Standard Oil of Cal., 332 U.S. 301, 316-17 (1947).

92. City of Bridgeton v. B. P. Oil, Inc., 369 A.2d 49, 54-55 (N.J. Super. Ct. Law Div. 1976).

93. Walker Cty. v. Tri-State Crematory, 643 S.E.2d 324, 327 (Ga. Ct. App. 2007).

94. E.g., Cty. of Erie v. Colgan Air, Inc., 711 F.3d 147, 154 (2d Cir. 2013) (holding that the county could not bring an action against airline to recover the costs of emergency and clean-up services it incurred when responding to airplane crash).

95. 954 F.2d 1279, 1310 (7th Cir. 1992).

96. Napa State Hosp. v. Yuba Cty., 71 P. 450, 452 (Cal. 1903).

97. Allenton Volunteer Fire Dep't v. Soo Line R. Co., 372 F. Supp. 422, 423 (E.D. Wis. 1974); Town of Howard v. Soo Line RR Co., 217 N.W.2d 329, 330 (Wis. 1974).
}

98. City of Bridgeton v. B. P. Oil, Inc., 369 A.2d 49, 54-55 (N.J. Super. Ct. Law Div. 1976). 
District of Columbia alleged negligence on the part of an airline and sought to recover the expenses that they incurred in rescuing survivors, recovering the bodies of the deceased, and raising the airplane and its contents from the river. ${ }^{99}$ The court held that "public funds expended in the "performance of governmental functions such as the emergency service provided by plaintiff following the crash... are not recoverable in tort." 100

Although the doctrine broadly denies government recovery for "public expenditures made in the performance of governmental functions[,]"101 it is not without limitations and exceptions. First, the doctrine does not bar recovery of public service expenditures expressly authorized by statute. ${ }^{102}$ Second, it allows recovery of public service costs where contracts provide for recovery. ${ }^{103}$ Third, federal courts have ruled that recovery is not barred where government public service expenditures are necessary to abate a nuisance. ${ }^{104}$ Finally, federal courts have found that governmental entities can recover from tortfeasors for damage to public lands, buildings, or equipment. ${ }^{105}$

Despite those exceptions and limitations in federal common law, the doctrine remains quite strong in Georgia, and thus may be driving the nearunanimity of Georgia city and county plaintiffs joining the Ohio MDL. In the leading Georgia case of Walker County v. Tri-State Crematory, the county brought a negligence and public nuisance action against the crematorium, on whose property human remains were found, and the funeral homes that sent bodies to the crematorium, to recover the costs that

\footnotetext{
99. District of Columbia v. Air Fla., Inc., 750 F.2d 1077, 1078 (D.C. Cir. 1984).

100. Id. at 1079 (internal quotation marks omitted).

101. Koch v. Consol. Edison Co., 468 N.E.2d 1, 8 (N.Y. 1984).

102. See Cherry Hill Twp. v. Conti Constr. Co., 527 A.2d 921, $922-23$ (N.J. Super. Ct. App. Div. 1987) (denying the Township from bringing an action against construction company, which had accidentally ruptured natural gas main, to recover damages for expenses incurred in providing services to meet the emergency caused by the rupture), superseded by statute, N.J. Stat. Ann. § 2A:62A-21 (West 2019), as recognized in In re Lead Paint Litig., 924 A.2d 484, 502 n.9 (N.J. 2007).

103. S. California Edison Co. v. United States, 415 F.2d 758, 759 (9th Cir. 1969) (per curiam) (granting the government reimbursement for cleanup costs against a polluter based on a land-use permit conditioned on the payment of such costs).

104. See, e.g., United States v. Ill. Terminal R. Co., 501 F. Supp. 18, 19 (E.D. Mo. 1980) (holding that "[r]ecent federal court decisions reflect[ed] a growing recognition of suits by government agencies under federal common law for the abatement of public nuisances."); see also City of Evansville v. Kentucky Liquid Recycling, Inc., 604 F.2d 1008, 1017-21 (7th Cir. 1979) (holding that plaintiffs could recover their water-treatment costs from defendants under "federal common law" of interstate water pollution).

105. See, e.g., Pennsylvania v. Gen. Pub. Utils. Corp., 710 F.2d 117, 122-23 (3d Cir. 1983) (holding that the government should have been able to present evidence that radioactive material released due to the defendants' negligence-created property damage rendered city buildings unsafe and unusable, upon which the government could recover resulting economic losses).
} 
the county had incurred in recovering, moving, storing, and identifying the remains. ${ }^{106}$ The defendants invoked the free public services doctrine to bar the county's claims. ${ }^{107}$ The county countered that it still could seek recovery for negligence and public nuisance. ${ }^{108}$

The court rejected the county's argument, reasoning that because local governments were established by the legislature "to provide core services for the public and pay for these services by spreading the costs to all citizens through taxation," the local government cannot reallocate how those costs are spread via tort claims through the judicial system. ${ }^{109}$ The court relied on an earlier case, Torres v. Putnam County, in which Putnam County sought injunctive relief against business operators who were unlawfully occupying buildings on their property without obtaining required inspections, certificates of occupancy, and the like. ${ }^{110}$ Putnam County also sought tort damages for the expense of sending the building inspector and sheriff to the property. ${ }^{111}$ The trial court's dismissal was affirmed on the grounds that the county's injury was experienced in "enforcing its laws and protecting its citizens" and was thus not compensable under tort law. ${ }^{112}$

Although following and applying the Putnam County precedent, the Walker County court allowed two exceptions to the doctrine: First, the government could recover under specific statutory authorization; and second, the government could recover for damage to government-owned property. ${ }^{113}$ The first exception did not apply because Walker County had not shown a specific statute that would allow them to recover damages for abating a public nuisance. ${ }^{114}$ The second exception did not apply because Walker County was not seeking to recover damages associated with an injury to its property but rather to recover the costs of the public service of cleaning up the site. Therefore, the court concluded that "whether or not the carrying out of a public service was mandatory or discretionary" the

\footnotetext{
106. Walker Cty. v. Tri-State Crematory, 643 S.E.2d 324, 325-26 (Ga. Ct. App. 2007).

107. Id. at 326 .

108. Id. at 327.

109. Id. (internal quotation marks omitted).

110. 541 S.E.2d 133, 134 (Ga. Ct. App. 2000).

111. Id.

112. Id. at 136-37.

113. Walker Cty. v. Tri-State Crematory, 643 S.E.2d 324, 327 (Ga. Ct. App. 2007).

114. Id. Walker County did cite to Ga. Code Ann. § 31-21-26 (West 2018), which states that "[n]either the state, county, municipality, nor officers thereof shall be placed at any expense by reason of delivery or distribution of bodies," but the court held that this statute "refer[red] to the delivery or distribution of unclaimed bodies for purposes of medical research," when read in context with its surrounding provisions. Walker Cty, 643 S.E.2d at 328. They further held that the two situations were too different to allow the County to recover under the statute. Id.
} 
free public services doctrine barred the county's negligence and public nuisance claims. ${ }^{115}$

Should the cases be remanded to state court or adjudicated under state law, the free public services doctrine could stand as a serious obstacle to local governments' recovery. That said, there is one possible line of argument, which at least one court found persuasive. ${ }^{116}$ On June 18, 2018, Suffolk County New York Judge Jerry Garguilo declared that the plaintiffs had presented more than enough evidence for their lawsuit to go forward and denied the defendants' motions to dismiss, with the exception of one defendant for which personal jurisdiction was lacking. ${ }^{117}$ With respect to the municipal cost recovery rule argument, Judge Garguilo noted that the claims did not involve damages claims for "the normal provision of police, fire and emergency services," "118 but rather sought to "remedy public harm caused by an intentional, persistent course of deceptive conduct."119 To accept the defendants' argument that "the municipal cost recovery rule forecloses the plaintiffs from recovering the costs for services to treat residents suffering from prescription opioid abuse, addiction or overdose, or for the increased costs of programs implemented to stem prescription opioid-related criminal activities," even when intentional, deceptive conduct that "mislead the public and prescribers about the risks of prescription opioids" is alleged, "would distort the doctrine beyond recognition." 120 City and county plaintiffs could rely on similar arguments to seek exception to the doctrine in other states.

\section{Advantages of MDL}

Although the MDL does not require the same degree of commonality and typicality as a full-blown federal class action, there may be advantages for individual local governmental units to proceed together. For one, the MDL is designed to consolidate and streamline pretrial discovery, which has been a priority for Judge Polster. He has coordinated plaintiffs' access to the federal Drug Enforcement Administration's (DEA) Automated Reports and Consolidated Ordering System (ARCOS) database ${ }^{121}$ of

\footnotetext{
115. Walker Cty, 643 S.E.2d at 329.

116. In re Opioid Litig., No. 400000/2017, 2018 WL 3115102 (N.Y. Sup. Ct. June 18, 2018).

117. Id. at $* 28$.

118. Id. at *11-12 (quoting City of Flagstaff v. Atchison, Topeka \& Santa Fe Ry. Co., 719 F.2d 322, 324 (9th Cir. 1983)).

119. Id. at $* 12$.

120. Id.

121. Automation of Reports and Consolidated Orders System (ARCOS), U.S. DEP'T OF JUST. DRUG ENFORCEMENT ADMIN., https://www.deadiversion.usdoj.gov/arcos/index.html [https://perma.
} 
controlled substances transactional records relevant to their local markets, ${ }^{122}$ and issued other uniform discovery orders. ${ }^{123}$ ARCOS provides, for both sides, the extent of involvement by any particular distributors. Another order particularly relevant to the local government costs question is the June 19, 2018 Fact Sheet Implementation Order, which calls for detailed responses from all government plaintiffs, including cities and counties, regarding their claimed injuries, damages, and persons with relevant knowledge. ${ }^{124}$ This discovery order originally had a ninety-day deadline ending on September 18, 2018, ${ }^{125}$ which was extended for an additional ninety days. ${ }^{126}$ The questions in the Government Plaintiff Fact Sheet overlap with but do not precisely track the personnel interviewed and types of information sought in our study.

Another advantage of the MDL posture is the potential to drive settlement pretrial. Quite overtly, that has been a goal of Judge Polster's in managing the MDL. ${ }^{127}$ On January 9, 2018, at the very first meeting of counsel in the MDL, he remarked:

People aren't interested in figuring out the answer to interesting legal questions like preemption and learned intermediary, or unravelling complicated conspiracy theories.

So my objective is to do something meaningful to abate this crisis and to do it in 2018 . . . .

....

... [W]e don't need a lot of briefs and we don't need trials. They're not going to - none of them are - none of those are going to solve what we've got. ${ }^{128}$

Judge Polster further expressed a commitment to accomplishing what

cc/3GT6-GGCF] (last visited Apr. 1, 2019) (“ARCOS is an automated, comprehensive drug reporting system which monitors the flow of DEA controlled substances from their point of manufacture through commercial distribution channels to point of sale or distribution at the dispensing/retail level . ...").

122. See, e.g., Order Regarding ARCOS Data, In re Nat'l Prescription Opiate Litig., No. 17-2804 (N.D. Ohio Apr. 11, 2018), ECF No. 233 (first of three ARCOS orders).

123. See, e.g., Order Regarding Designating Attorneys Addressing Coordination of State/Federal Discovery, In re Nat'l Prescription Opiate Litig., No. 17-2804 (N.D. Ohio June 13, 2018), ECF No. 616.

124. Fact Sheet Implementation Order, In re Nat'l Prescription Opiate Litig., No. 17-2804 (N.D. Ohio June 19, 2018), ECF No. 638.

125. Id. at 1 .

126. Report of Special Master entering Discovery Order for Track One Cases \& Amending Prior Orders at 6-7, In re Nat'l Prescription Opiate Litig., No. 17-2804 (N.D. Ohio Sept. 6, 2018), ECF No. 941.

127. Transcript of Proceedings at 4-5, In re Nat'1 Prescription Opiate Litig., No. 17-2804 (N.D. Ohio Jan. 9, 2018), ECF No. 58 [hereinafter Jan. 9 Proceeding].

128. Id. at $4,9$. 
state and federal elected officials thus far had failed to do in addressing the opioid crisis, ${ }^{129}$ drawing criticism for judicial activism and overstepping. ${ }^{130}$ He stated on record at the same January meeting of counsel: "The federal court is probably the least likely branch of government to try and tackle [the opioid epidemic], but candidly, the other branches of government, federal and state, have punted." 131 Given that stance, the question of settlement and, accordingly, damages becomes all the more important to nail down.

\section{B. Tribal Lawsuits}

As discussed more fully in Vice Chancellor Stacy Leeds's article in this issue, Native American tribes have been out ahead of states in both addressing and litigating the opioid epidemic. Those cases are particularly instructive for this cost study because tribal nation's health care and other services are provided within discrete jurisdictional boundaries. ${ }^{132}$ Moreover, tribes have been especially proactive in treatment and prevention around opioid addiction. The opioid crisis has had an especially severe impact in tribal nations. At a hearing before the Committee on Indian Affairs, chief medical officer of the Indian Health Service (IHS) reported that American Indians and Alaska Natives had the highest drug overdose death rates in 2015. Also, between 1999 and 2005, Native Americans' deaths by overdose increased by "more than 500 percent." 133 Native Americans comprise "only 2 percent of the total U.S. population" yet they "experience[] the highest rate of opioid-related fatalities ...."134 The root of the problem could be traced in part to the

129. Hoffman, supra note 10.

130. See Ryan J. Duplechin, What is the Role of the Judiciary in Tackling the Opioid Epidemic?, PETRIE-FLOM CTR. (June 15, 2018) http://blog.petrieflom.law.harvard.edu/2018/06/15/what-is-therole-of-the-judiciary-in-tackling-the-opioid-epidemic/ [https://perma.cc/5VGY-SL83]; Daniel Fisher, Judge Sees Litigation as Only an 'Aid in Settlement Discussions' for Opioid Lawsuits, FORBES (May 10, 2018 11:54 AM) https://www.forbes.com/sites/legalnewsline/2018/05/10/judge-sees-litigation-asonly-an-aid-in-settlement-discussions-for-opioid-lawsuits/\#6fe6d18c4b99 [https://perma.cc/7G7C4LLB]; see also Elizabeth Chamblee Burch \& Margaret S. Williams, Repeat Players in Multidistrict Litigation: The Social Network, 102 CORNELL L. REV. 1445, 1446 (2017) (critiquing repeat MDL attorneys' ability to influence the MDL rules because "the rules they develop may principally benefit them at the expense of one-shot plaintiffs").

131. Jan. 9 Proceeding, supra note 127 , at 4.

132. See generally Stacy L. Leeds, Beyond an Emergency Declaration: Tribal Governments and the Opioid Crisis, 67 U. KAN. L. REv. 1013 (2019) (discussing the Native American tribes' opioid litigation).

133. Opioids in Indian Country: Beyond the Crisis to Healing the Community: Hearing Before the S. Comm. on Indian Affairs, 115th Cong. 3 (Mar. 14, 2018) (statement of Michael E. Toedt, MD, Chief Medical Officer of the Indian Health Services) [hereinafter Hearing].

134. Suzette Brewer, Tribes Lead the Battle to Combat a National Opioid Crisis, High COUNTRY 
"over-prescription of painkillers at [IHS] hospitals and clinics across the country." 135

In addition to the death toll, the crisis also exacts heavy economic consequences on these already impoverished communities. For instance, many funds intended for basic human services, such as housing or elder programs, are "being redirected to pay for additional law enforcement, social services ... and ... treatment facilities and programs ...."136 The tribes also struggle with retaining physicians in remote rural area, which contributes to this crisis. ${ }^{137}$ Moreover, according to the chairman of the Chippewa Indians of Michigan, the tribes receive "direct services" from the IHS and "have little choice but to accept policies and procedures [believed to be] under the direct influence of the pharmaceutical industry." 138

Accordingly, the tribal governments sued opioid manufacturers, distributors, and retailers. In April 2017, the Cherokee Nation filed suit in tribal court against various defendants such as Wal-Mart, CVS, Cardinal Health, McKesson, and AmerisourceBergen. ${ }^{139}$ The complaint alleged that the defendants, by "turning a blind eye to known or knowable problems in their own supply chains," created "opioid diversion" 140 in the black market, which "caused and continue to cause a crisis that threatens the health, safety, and welfare of the citizens of the Cherokee Nation." 141 The tribe sought damages in the form of costs for (1) medical care for opioid-related patients, (2) counseling and rehabilitation, (3) treatment of infants born with conditions caused by opioids, (4) welfare for children whose parents are victims of the crisis, (5) law enforcement and public safety, and (6) lost productivity. ${ }^{142}$ U.S. District Court Judge Terence Kern enjoined the suit, holding that the Cherokee Nation Tribal Court lacked jurisdiction over non-native corporations and that the harm alleged was not sufficiently "catastrophic for tribal self-government" to warrant

\footnotetext{
NEws (May 9, 2018), http://www.hcn.org/articles/tribal-affairs-tribes-lead-the-battle-to-combat-anational-opioid-crisis [https://perma.cc/2HUB-R8LH].

135. Id.

136. Id.

137. Id.

138. Id.

139. Id.

140. Petition at 2, Cherokee Nation v. McKesson Corp., No. CV-17-203 (Cherokee Nation Dist. filed Apr. 20, 2017), https://turtletalk.files.wordpress.com/2017/04/petition-4-20-17.pdf [https://perma.cc/VU8R-B25W]. Opioid diversion is a phenomenon in which massive number of opioid pills are diverted from legitimate channels of distribution into the illicit black market.

141. Id. at 4 .

142. Id. at 3 .
} 
tribal jurisdiction. ${ }^{143}$ The tribe then filed the case in Sequoyah County State Court in Oklahoma. ${ }^{144}$

The jurisdictional conflict is between tribes' sovereign authority, on the one hand, and federal district courts' original jurisdiction over actions arising under federal law, on the other. ${ }^{145}$ Very early U.S. Supreme Court precedents specify that Native American tribes are "distinct, independent political communities, retaining their original natural rights" in matters of local self- government. ${ }^{146}$ While no longer "possessed of the full attributes of sovereignty," tribes remain a "separate people, with the power of regulating their internal and social relations...."147 Thus, tribal jurisdiction turns on whether the defendant is Native American and whether the events occurred within the geographic boundaries of the tribal community. ${ }^{148}$ More recently, in 1985, the U.S. Supreme Court affirmed that tribal remedies, including tribal courts' adjudication of jurisdictional matters, ${ }^{149}$ must be exhausted before federal district courts may hear them. ${ }^{150}$

As noted, tribal jurisdiction is limited. For one, tribes generally lack jurisdiction over non-tribal members. ${ }^{151}$ An exception exists, however, if the defendant entered a consensual commercial relationship with the tribe. ${ }^{152}$ Consensual commercial relationships include private contracts according to the U.S. Supreme Court. ${ }^{153}$ The opioid defendants argued, however, that selling or distributing products via commercial pharmacies and insurers does not establish that sort of agreement with the tribe, thus,

\footnotetext{
143. McKesson Corp. v. Hembree, No. 17-CV-323, 2018 WL 340042, at *8 (N.D. Okla. Jan. 9, 2018).

144. See Original Petition, Cherokee Nation v. McKesson Corp. (Okla. Dist. Ct. Sequoyah Cnty. filed Jan. 19, 2018)

145. 28 U.S.C. $\S 1331$ (2012).

146. Worcester v. Georgia, 31 U.S. 515, 559 (1832).

147. United States v. Kagama, 118 U.S. 375, 381-82 (1886).

148. E.g., Oliphant v. Suquamish Indian Tribe, 435 U.S. 191 (1978) (denying tribal criminal jurisdiction over non-Indian defendants).

149. Strate v. A-1 Contractors, 520 U.S. 438, 459-60 (1997).

150. Nat'l Farmers Union Ins. Cos. v. Crow Tribe of Indians, 471 U.S. 845, 856-57 (1985); Jan Hoffman, In Opioid Battle, Cherokee Want Their Day in Tribal Court, N.Y. TiMES (Dec. 17, 2017), https://www.nytimes.com/2017/12/17/health/cherokee-opioid-addiction-pharmacies.html [https://perma.cc/Y8MC-8WN3] (quoting Professor Lindsay Robertson, University of Oklahoma College of Law).

151. See Nat'l Farmers Union Ins. Cos., 471 U.S. at 852-54.

152. Montana v. United States, 450 U.S. 544, 565-66 (1981); see also Hoffman, supra note 150.

153. Montana, 450 U.S. at 565; see also Gabriel S. Galanda, Getting Commercial in Indian Country, A.B.A. BUS. L. SEC. (2003), https://apps.americanbar.org/buslaw/blt/2003-07-08/ galanda.html [https://perma.cc/4AXS-HU8V].
} 
the arrangement does not invoke the exception. ${ }^{154}$ Even medications provided to patients via IHS facilities do not constitute such an agreement because IHS ultimately is funded by the federal government. ${ }^{155}$

Given the jurisdictional scuffle in the Cherokee Nation case, other tribes that initiated opioid litigation mostly have filed in federal courts. The St. Croix Chippewa Indians filed in federal court in Wisconsin, and the Flandreau Santee Sioux and the Rosebud Sioux tribes filed in federal court in South Dakota. Both suits alleged that defendants "flooded their territories with opioids and failed to prevent the diversion of these drugs," along with violation of state consumer protection law. ${ }^{156}$ Another tribe, the Coyote Valley Band of Pomo Indians, brought a tort claim in California state court. ${ }^{157}$ Tension remains among tribal advocates regarding the merits of the federal MDL versus state courts. Again, perhaps recognizing the momentum of the MDL, in October 2018, three days before Columbus/Indigenous Peoples Day, four hundred forty-eight tribes filed an historic amicus brief in the federal MDL, asserting the especially devastating impact of the opioid epidemic on tribes and particular sovereign interests implicated. ${ }^{158}$ On similar grounds, the litigant tribes successfully sought a separate track in the MDL, ${ }^{159}$ along with Alabama, the original state in the MDL. ${ }^{160}$

The tribes' experience and litigation process may be instructive to this cost study because, first, the impact of the epidemic has been especially dramatic on their communities; second, the tribes have been out in front of the crisis in various regards; and, third, the costs may be easier to identify within a discrete sovereign nation. On the first point, in addition

154. Plaintiffs' Motion for Preliminary Injunction and Brief in Support at 15-16, McKesson Corp. v. Hembree, No. 17-cv-323 (N.D. Okla. June 8, 2017), ECF No. 13.

155. See Hoffman, supra note 150.

156. Robin T. Tipps et al., The Opioid Epidemic in Indian Country, 46 J. L., MED. \& ETHICs 422, 433 (2018).

157. Id.

158. Brief Amici Curiae of 448 Federally Recognized Tribes in Opposition to Defendants' Motions to Dismiss Tribal Claims, In re Nat'1 Prescription Opiate Litig., No. 17-2804 (N.D. Ohio Oct. 5, 2018), ECF No. 1026; see Amanda Bronstad, 448 Indian Tribes File 'Historic' Amicus Brief in Opioid Lawsuits, LAw.COM (Oct. 11, 2018), https://www.law.com/2018/10/11/448-indian-tribes-filehistoric-amicus-brief-in-opioid-lawsuits/ [https://web.archive.org/web/20181012133149/ https://www.law.com/2018/10/11/448-indian-tribes-file-historic-amicus-brief-in-opioid-lawsuits/].

159. Order Re: Reassigning Workload, In re Nat'l Prescription Opiate Litig., No. 17-2804, ECF No. 549; see Andrew Westney, Hard Hit by Opioids, Tribes to Get Own Track Within MDL, LAW360 (June 5, 2018), https://www.law360.com/articles/1050463/hard-hit-by-opioids-tribes-to-get-owntrack-within-mdl.

160. Melissa D. Berry, Opioid Litigation - Hundreds of Cases Consolidated, THOMAS ReUTERS (Sept. 28, 2018), http://www.legalexecutiveinstitute.com/opioid-litigation-consolidated/ [https://perma.cc/P9KZ-CT8F]. 
to the death toll recounted above, the crisis also exacts heavy economic consequences on already impoverished Native American communities. As noted, many funds intended for basic human services, such as housing or programs for the elderly have been redirected to address the opioid epidemic. ${ }^{161}$ In addition, there is a suggestion that the structure of IHS funding and administration may make medical services with tribal lands especially susceptible to pharmaceutical industry control. ${ }^{162}$ Various factors may support that potential, including the Joint Commission's pain scale and pharmaceutical marketing for increased prescribing, as opposed to other pain management strategies. The provider shortages may lead to prescriptions being written for longer durations of time between refills, and the direct payment design of IHS may reduce oversight.

Structurally, IHS is a division of the U.S. Department of Health and Human Services (HHS) and is responsible for providing "federal health services to American Indians and Alaska Natives." 163 IHS is the only division of HHS whose "primary function is direct delivery of health care." 164 By contrast, for example, Medicare and Medicaid operate as federal health insurance programs, paying for, but not directly providing, medical care or services. Treaties between the United States and tribes obligate the federal government to appropriate funds to IHS annually. ${ }^{165}$ The actual health care services may be provided by IHS, tribal entities, or Urban Indian Health Program, using the federal funds. Those facilities generally do not charge or bill any patients regardless of their insurance status. ${ }^{166}$ As an alternative, tribes may enter into Tribal Self-Governance Programs if they can show under Public Law 93-638 the economic and personnel resources sufficient to provide health care for their communities. ${ }^{167}$ In any case, direct provision of health care, without the overlay of managed care strategies that public and private insurers have utilized to hold down costs, ${ }^{168}$ as well as Medicare value-based purchasing

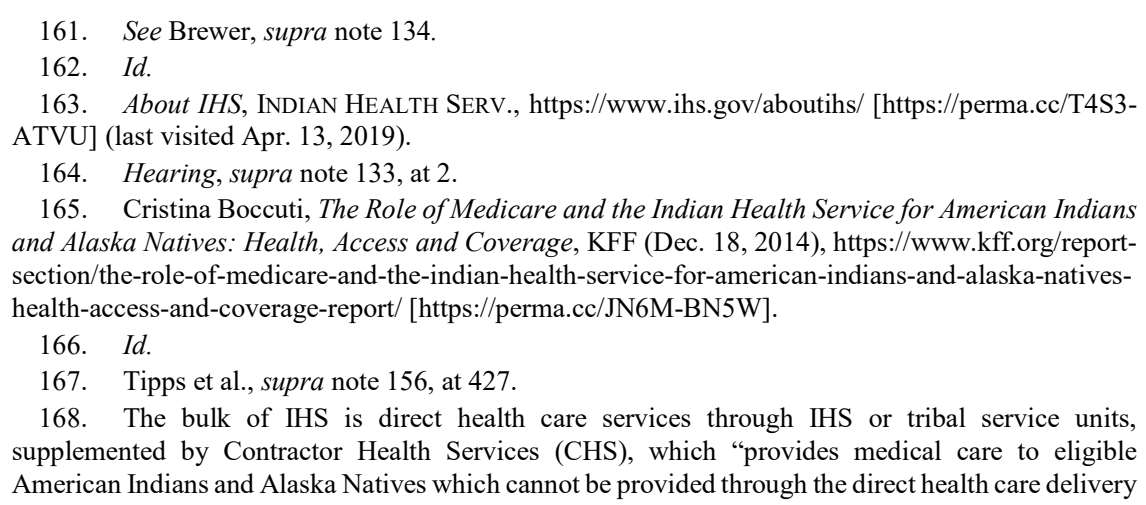

165. Cristina Boccuti, The Role of Medicare and the Indian Health Service for American Indians and Alaska Natives: Health, Access and Coverage, KFF (Dec. 18, 2014), https://www.kff.org/reportsection/the-role-of-medicare-and-the-indian-health-service-for-american-indians-and-alaska-nativeshealth-access-and-coverage-report/ [https://perma.cc/JN6M-BN5W].

166. Id.

167. Tipps et al., supra note 156 , at 427.

168. The bulk of IHS is direct health care services through IHS or tribal service units, supplemented by Contractor Health Services (CHS), which "provides medical care to eligible American Indians and Alaska Natives which cannot be provided through the direct health care delivery 
and conditions of participation designed to improve quality of care, may not operate as robustly within IHS. ${ }^{169}$

Although the structure and administration of IHS may exacerbate the opioid crisis, tribal nations also have taken the lead in various other respects to address the opioid epidemic. Tribes have been on the forefront of employing medication-assisted treatment (MAT) and culturally cognizant counseling services. ${ }^{170}$ In addition, Public Law 93-638 qualified tribes, which "receive an annual lump-sum ... funding that would otherwise be used by IHS to provide direct care services," have supplemented that fund with revenues from tribal economic ventures to "renovate[] or construct[] their own hospitals and outpatient clinics" and "redesign health programs according to the needs of the community," 171 creating another avenue for innovative treatment. Tribes also were proactive in tracking prescription drugs. In July 2016, a few months after Congress passed a law ${ }^{172}$ that made it "virtually impossible for the DEA to freeze suspicious narcotic shipments from [pharmaceutical] companies," 173 IHS implemented the Prescription Drug Monitoring Programs (PDMP), aiming to "strengthen[] . . monitoring and deterrence of prescription misuse and diversion." ${ }^{174}$ IHS was "the first federal medical agency to require providers to check state [PDMP] databases prior to prescribing and dispensing opioids for treatment longer than seven days." 175 IHS also requires pharmacies to report opioid prescribing data to state PDMPs, although not expressly required by state or federal laws. ${ }^{176}$ In March 2017, IHS chartered the National Committee on Heroin Opioids and Pain Efforts (HOPE) to effectively coordinate patient care and conduct

system.” Indian Health SeRV., Contract Health Services Fund Control, Circular No. 91-07, Sec. 2 (June 13, 1991), https://www.ihs.gov/ihm/circulars/1991/contract-health-services-fund-control/ [https://perma.cc/28NL-S4G6]. CHS is subject to various managed care requirements, including gatekeeping, utilization review, cost sharing, claims processing, and data analysis. Id. at 4.C.

169. See Daniel R. Levinson, Dep'T of Health \& Human Servs., Office of Inspector Gen., INDian Health SERVice Hospitals: More Monitoring NEEDED to ENSURE Quality CARE 4 (2016), https://oig.hhs.gov/oei/reports/oei-06-14-00010.pdf [https://perma.cc/WP8N-F9YJ].

170. Eric Wicklund, HHS Grants to Help Native Americans Expand Telehealth Resources, MHEALTH INTELLIGENCE (Sept. 27, 2018), https://mhealthintelligence.com/news/hhs-grants-to-helpnative-americans-expand-telehealth-resources [https://perma.cc/GFN7-ZNKV].

171. Tipps et al., supra note 156, at 427.

172. Ensuring Patient Access and Effective Drug Enforcement Act of 2016, Pub. L. No. 114-145, $\S 2$ (a)(1), 130 Stat. 354 (codified at 21 U.S.C. § 823 (2012 \& Supp. 2017)).

173. Scott Higham \& Lenny Bernstein, The Drug Industry's Triumph Over the DEA, WASH. POST (Oct. 15, 2017), http://www.washingtonpost.com/graphics/2017/investigations/dea-drugindustry-congress/?noredirect=on\&utm_term=.dc5f3b99f8de [https://perma.cc/S6UR-N77F].

174. Hearing, supra note 133 , at 4 .

175. Tipps et al., supra note 156, at 428.

176. Hearing, supra note 133, at 4. 
research in cases of substance abuse. ${ }^{177}$

The tribal nations are in a unique position to accurately estimate damages from the lawsuits. As discussed above, the healthcare system is effectively centralized within IHS - either IHS directly delivers healthcare services, or tribes get funding through Public Law contracts. As part of the process of annual funding, IHS is required to submit to the federal government a detailed budget request following specific formulation guidelines. ${ }^{178}$ Moreover, the Government Performance and Results Act (GPRA) requires all federal agencies, IHS included, to demonstrate that "they are using their funds effectively toward meeting their missions"; accordingly, IHS carefully tracks its activities and performance measures for annual reporting. ${ }^{179}$ For instance, in March 2018, IHS received a ten percent increase in funding and allocated five million dollars to the Opioid Response Grant Fund and Medication-Assisted Treatment Program. ${ }^{180}$ Due to these requirements and the structure of the health care delivery system in tribal nations, the IHS is uniquely postured to track, identify, and categorize the costs related to opioid treatment in ways that local governments are not.

Given the high rates of opioid abuse disorder and related issues in Native American tribes, the impact on children, including newborns, within those communities has also been significant. Newborns exposed to opioids during the mother's pregnancy often experience Neonatal Abstinence Syndrome (NAS). The Substance Abuse and Mental Health Services Administration (SAMHSA), a division of HHS, oversees surveillance, data collection, and policy recommendations around the issue of prenatal substance exposure. ${ }^{181}$ This data includes a populationlevel survey on substance use and mental health, substance use disorder treatment, and facility-level data on substance use disorder treatment, with

177. IHS National Committee on Heroin Opioids and Pain Efforts, Indian Health SeRV., https://www.ihs.gov/hope/ [https://perma.cc/4TUH-V8UW] (last visited Apr. 2, 2019).

178. Annual Budget, INDIAN HEALTH SERV., https://www.ihs.gov/aboutihs/annualbudget/ [https://perma.cc/BPY7-UYCY] (last visited Apr. 13, 2019).

179. GPRA and Other National Reporting, INDIAN HEALTH SERV., https://www.ihs.gov/crs/ gprareporting/ [https://perma.cc/2GLK-73HV] (last visited Apr. 13, 2019).

180. Consolidated Appropriations Act, 2018, Pub. L. No. 115-141, 132 Stat. 348, 676-80; Stephanie Valenzuela, In Plain Sight: How the Opioid Crisis has Ravaged Indian Country, LAKOTA PEOPLE's L. PROJECT (July 5, 2018), http://www.lakotalaw.org/news/2018-07-05/opioid-crisis [https://perma.cc/9PEW-RURT].

181. Behavioral Health Coordinating Council Subcomm. on Prescription Drug Abuse, Protecting Our Infants ACt: RePort to CONGRess 14, https://www.samhsa.gov/ sites/default/files/topics/specific_populations/protecting-our-infants-act-report-congress-2017.pdf [https://perma.cc/UYF9-FSWF] (last visited Apr. 2, 2019). 
particular attention to Native American tribes in various points. ${ }^{182}$ For opioid-exposed babies, IHS incurs additional costs for hospitalization and medication during the withdrawal, as well as transportation and care of the infants. ${ }^{183}$ In addition, Native American children affected by opioids may face particular challenges with respect to child welfare services. The foster care system may become involved when the children cannot live at home due to addicted parents or the birth parents choose not to parent. NAS newborns "are given morphine treatments to ensure they ... don't encounter the dangerous side effects of withdrawing too quickly" and are weaned off after a few weeks, but "they can be fussy, hard to console and take care of" in the process, which deters potential foster families. ${ }^{184}$ Placement of these children also is complicated under the Indian Child Welfare Act. A provision of the Act places preference for other family members, then a family within the tribe or any other Native American Indian before the child may be adopted by other families. ${ }^{185}$ On October 12, 2018, U.S. District Judge Reed O'Connor held that provision unconstitutional for violating equal protection. ${ }^{186}$ Expanding the pool of potential foster or adoptive families may assist in the care of babies born exposed to opioids, but may have other serious costs, including an existential threat to tribal nations, since most of them are small communities and fear permanent placement of their future generations outside the tribe.

Given the sovereign status of tribes, the unique impacts of the opioid crisis in those communities, health and welfare delivery structures, and tribes' proactive approach to addressing the opioid epidemic, they provide a unique case study, although full discussion is beyond the scope of this Article. One relevant takeaway point, however, is that it may be much easier to isolate tribal opioid costs, as compared to city and county government opioid costs. Health care costs are well documented through annual reports to Congress, and tribal versus federal funding can be readily identified. Other opioid-related expenditures, including under-contract purchases from non-IHS providers and pharmacies, and budget

\footnotetext{
182. Id.

183. Kristi Eaton, Opioid Epidemic Threatens the Children - and Future - of Cherokee Nation, THE LILY (May 3, 2018), http://www.thelily.com/opioid-epidemic-threatens-the-children-and-futureof-cherokee-nation/ [https://perma.cc/Z9L3-FMSM].

184. Id.

185. 25 U.S.C. $\S 1915(a)-(b)(2012)$.

186. Brackeen v. Zinke, 338 F. Supp. 3d 514, 531-36 (N.D. Tex. 2018); see Joe Bowen, Texas Judge Rules Indian Child Welfare Act Unconstitutional: Ruling Could Have National Impact, DULUTH NewS TRIB. (Oct. 12, 2018, 7:02 PM), http://www.duluthnewstribune.com/news/government-andpolitics/4513139-texas-judge-rules-indian-child-welfare-act-unconstitutional [https://perma.cc/ 4LZJ-4SFQ].
} 
reallocations are also apparent. Various policy innovations, including MAT and PDMP, offer best practices that non-tribal governmental units may consider in addressing the opioid epidemic.

\section{Progress at the $M D L$}

As of this writing, the local government and other cases are still pending at the MDL. Progress has been made over the past year since the MDL was constituted, but settlement discussion and damages assessments remain illusory. Early in the process, last winter, on January 11, 2018, Judge Polster issued an order appointing three special masters to assist with the litigation: David R. Cohen, Francis McGovern, and Cathy Yanni. ${ }^{187}$ David Cohen is a federal special master who has had years of experience in mediation, arbitration, and court monitoring. ${ }^{188} \mathrm{Mr}$. Cohen was appointed special master in nearly twenty multidistrict litigation and other class actions, including mass tort, national health crisis, and Fair Labor Standards Act (FLSA) class actions. ${ }^{189}$ Francis McGovern is a professor at Duke University School of Law. ${ }^{190}$ Professor McGovern has served as a court-appointed special master in over seventy complex cases and has "developed solutions in most of the significant mass claim litigation in the U.S." and abroad, including the United Nations Compensation Commission, DDT toxic exposure litigation in Alabama, and silicone gel breast implant litigation. ${ }^{191}$ Cathy Yanni is a panelist with JAMS, "the largest private provider of [mediation and arbitration] services worldwide," and has served as settlement special master in over twenty large pharmaceutical and medical device cases, in addition to multiple class actions and MDL cases in the past. ${ }^{192}$

On January 31, 2018, Judge Polster held a closed-door session with tiers of lead lawyers, and their experts and clients. According to three people in attendance of the meeting, the experts and Attorneys General recommended that Purdue's eighty-milligram version of OxyContin,

187. Appointment Order at 1, In re Nat'l Prescription Opiate Litig., No. 17-2804 (N.D. Ohio Jan. 11, 2018), ECF No. 69.

188. David $R$. Cohen Resume, David R. Cohen Federal Special Master, https://www.specialmaster.law/resume/ [https://perma.cc/N5N6-X4KR] (last visited Apr. 13, 2019).

189. Id.

190. Francis McGovern, DuKE LAW, https://law.duke.edu/fac/mcgovern/ [https://perma.cc/ R9W7-Y4HL] (last visited Apr. 13, 2019).

191. Id.

192. JAMS Panelist Cathy Yanni Named as a Special Master in Opioid MDL, JAMS (Jan. 17, 2018), https://www.jamsadr.com/news/2018/jams-panelist-cathy-yanni-named-as-a-special-masterin-opiod-mdl [https://perma.cc/55KQ-QQPB]; see also Cathy Yanni, JAMS, https://www.jamsadr.com/yanni/ [https://perma.cc/4UZ2-QRP4] (last visited Apr. 13, 2019). 
which is often crushed and snorted by abusers, be removed from the market. ${ }^{193}$ Setting aside the fact that an MDL judge lacks formal regulatory authority, or even clear authority over the merits of the litigation, ten days later, on February 9, 2018, Purdue announced that it would no longer market OxyContin to prescribers. ${ }^{194}$ An expert in the addiction field, Dr. Anna Lembke from Stanford University, attributed this "radical reversal" by Purdue, which has long contended that it had not influenced physicians with its drug representations, to "overwhelming pressure from Judge Polster." 195 Another plausible explanation is the "pressure to rehabilitate [the] company['s] reputation damaged by litigation and other publicity" by taking an affirmative step to contribute to the solution. ${ }^{196}$

On February 2, 2018, Judge Polster issued an Order directing the plaintiffs and the DEA to discuss the scope of ARCOS database production. ${ }^{197}$ ARCOS requires manufacturers and distributors to report their controlled substances transactional records to the DEA. ${ }^{198}$ The information is "collected and compiled by DEA . . for determining quota, distribution trends, internal audits, and other analyses." 199 Every time one of the controlled substance pills is sold, it is reported to the database, regarding "where the pill[] went, where [it was] sold and sort of the market share situation." 200 Access to the database would provide the plaintiffs with knowledge of "the extent of involvement by any particular distributor and where maybe [they] need to focus more ... efforts." ${ }^{201}$ The DEA represented that it could provide information regarding large manufacturers, by state, for a two-year period from 2012 to $2013 .{ }^{202}$ In a hearing on February 26, 2018, the court directed the attorney for

193. Jef Feeley, Purdue's Oxycontin Targeted at Judge's Opioid Summit, BLoOMBERG (Feb. 2, 2018, 3:00 AM), http://www.bloomberg.com/news/articles/2018-02-02/purdue-s-oxycontin-said-tobe-targeted-at-judge-s-opioid-summit.

194. Purdue Pharma L.P. Issues Statement on Opioid Promotion, PURDUE PHARMA L.P. (Feb. 9, 2018), http://www.purduepharma.com/news-media/2018/02/purdue-pharma-1-p-issues-statementon-opioid-promotion/ [https://perma.cc/T8K6-G5UX].

195. Hoffman, supra note 10.

196. See Gluck et al., supra note 11, at 360 .

197. Minutes of 2/26/18 Hearing and Order at 1, In re Nat'1 Prescription Opiate Litig., No. 172804 (N.D. Ohio Mar. 1, 2018), ECF No. 155 [hereinafter Feb. 26 Hearing].

198. ARCOS Retail Drug Summary Reports, U.S. DeP'T OF Justice Drug ENForCement ADMIN., $\quad$ https://www.deadiversion.usdoj.gov/arcos/retail_drug_summary/index.html [https://perma.cc/KJ9R-2D75] (last visited Apr. 13, 2019); see 21 U.S.C. § 827(d)(1) (2012 \& Supp. 2016).

199. ARCOS Retail Drug Summary Reports, supra note 198.

200. Jan. 9 Proceeding, supra note 127, at 16.

201. Id.

202. Feb. 26 Hearing, supra note 197, at 2. 
DEA/DOJ to file a document by March 5, 2018, setting forth the authorization and length of time to produce information regarding manufacturers and distributors by states for a nine-year period from 2006 through $2014 .^{203}$

Following two months of settlement talks, Judge Polster allowed lawyers to proceed with some discovery and motion filings. ${ }^{204}$ "On March 6,2018 , the Court met with the parties' negotiating teams, liaison counsel and representatives of numerous State Attorneys General to discuss the status of settlement negotiations." ${ }^{205}$ The parties reported both substantial progress and "various barriers to a global resolution." 206 Judge Polster directed the parties to submit to the special masters, by March 16, 2018, "their suggestions regarding the appropriate scope and timing of a litigation track and the contents of a case management order ('CMO'), including identification of test cases, sequencing of discovery, timing of motion practice (including issues related to remand), and any other relevant matters." 207 In the same order, the judge also directed special masters to continue settlement talks with the MDL attorneys, and scheduled a May 10, 2018 settlement conference. ${ }^{208}$

On April 11, 2018, the court entered an ARCOS Data Order, directing the DEA to produce information regarding manufacturers and distributors for six states for the period of nine years from January 1, 2006, to December 31, 2014. ${ }^{209}$ The six states were Ohio, West Virginia, Illinois, Alabama, Michigan, and Florida. ${ }^{210}$ Commenting on the usefulness of the data, such as allowing plaintiffs to identity previously unknown companies to add to the complaints, the court issued the Second ARCOS Order on May 7, 2018, expanding the scope to the entire United States for the same period. ${ }^{211}$ On June 26, 2018, the Court issued the Third ARCOS Order, directing the DEA to supplement missing information on certain relevant chemicals. $^{212}$

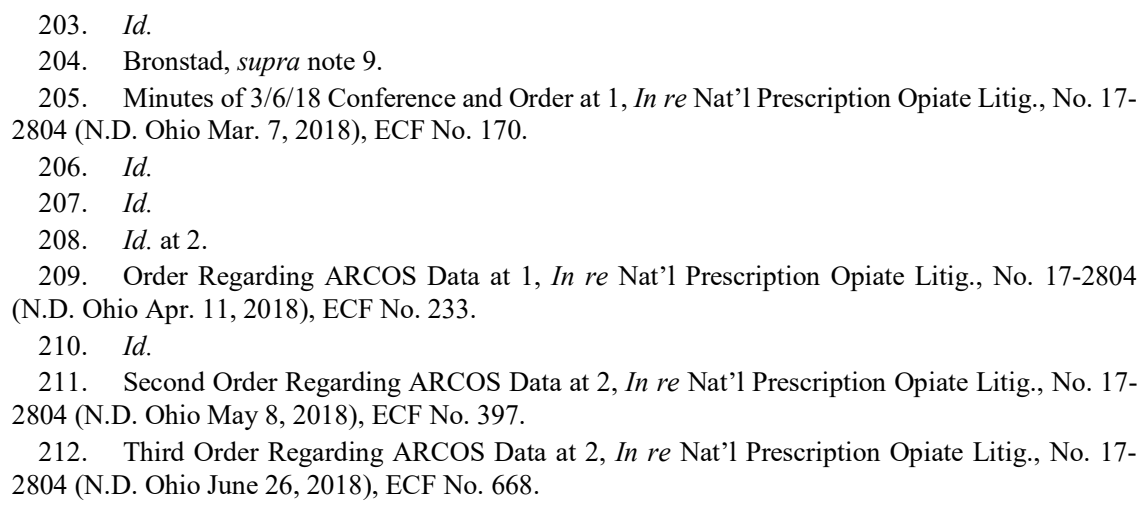


On June 19, 2018, the court issued another discovery order ${ }^{213}$ requiring both parties to provide a completed Fact Sheet within ninety days. ${ }^{214}$ This Government Plaintiff Fact Sheet is particularly pertinent to our study, in that it asks the plaintiffs to provide documentation supporting their damages allegations, which include several categories: (1) increased costs for first responders, including EMT and ambulance charges, cost of payment for improper prescriptions, public hospital charges, Narcan/Naxolone administration and training costs, opioid treatment and prevention programs; (2) law enforcement and incarceration costs, which includes Drug Task Force, operating cost for Drug Accountability courts, and costs associated with inmates, transportation, and healthcare treatment in prison; (3) mortality costs, which range from costs in indigent burial, transportation, and morgue space, to costs in assisting with the foster children whose family members were victims of the opioid crisis; (4) rehabilitation costs, covering drug abuse treatment, counseling, and education programs. ${ }^{215}$ That discovery request called for extensive, detailed disclosures related to the plaintiffs' claimed damages, dating back ten years, to January $1,2008 .^{216}$

Judge Polster has also ordered a series of “'bellwether trials,' or test cases that give attorneys an idea of how future cases may play out," to begin in $2019 .{ }^{217}$ The nature of the litigation, along with the scope of discovery and expanding list of defendants, "has made it particularly challenging to contain within traditional legal procedures." 218 The first trial was set for March 2019, later delayed six months to November 2019, and "will include claims made by the city of Cleveland and Cuyahoga and Summit counties in Northeast Ohio." "219 Setting trial dates at all, plus the

213. Fact Sheet Implementation Order, In re Nat'l Prescription Opiate Litig., No. 17-2804 (N.D. Ohio June 19, 2018), ECF No. 638.

214. Id. at 1; see complaints cited supra note 14 (listing damages allegations).

215. See complaints cited supra note 14.

216. Government Plaintiff Fact Sheet at 2-5, In re Nat'l Prescription Opiate Litig, No. 17-2804 (N.D. Ohio June 19, 2018), ECF No. 638-1 (requesting a range of information, dating back to January 1,2008 , including annual expenditures for law enforcement, courts, corrections, public health, child welfare, workers compensations, and health insurances; every health care provider and pharmacy that has been a target of law enforcement or administrative investigation related to opioid prescribing or dispensing; names of various local government elected and appointed leaders also department heads, also dating back to January 1, 2008).

217. Eric Heisig, Cleveland Federal Judge Over Opioid Litigation Orders DEA to Release Painkiller Sales Data For Entire U.S., http://www.cleveland.com/courtjustice/index.ssf/2018/05/cleveland_federal_judge_over_o.html [https://perma.cc/V3LJ-R9B5] (May 9, 2018).

218. O'Brien, supra note 24.

219. Heisig, supra note 217; Jeff Overley, Opioid MDL Bellwether Trial Postponed 6 Months, LAw360 (Aug. 13, 2018, 8:26 PM), https://www.law360.com/articles/1072924/opioid-mdlbellwether-trial-postponed-6-months. 
delay, is notable given Judge Polster's initial insistence on speedy and non-merits-based resolution of the cases. Such was the status of the MDL at the time we initiated our interviews with local government department heads and assessment of their ability to quantify these and other opioidrelated costs. Before describing our study, however, we next survey other studies estimating the financial impact of the opioid crisis, which, for reasons we explain below, are very difficult to translate into usable cost estimates at the city or county level.

\section{EXISTING OPIOID COST STUDIES}

Calculating an accurate number to reflect the financial cost on local governments caused by the opioid crisis requires creative and careful thought about the various potential cost impacts as well as appreciation for the fact that, at least in some locations, some of the more obvious costs will not be borne by local governments. As noted above, government healthcare programs are funded at the federal and state, and not local, level. In Georgia, local public health departments and child welfare agencies also are state-funded, although that arrangement will differ in other jurisdictions. School districts are separate governmental units with their own funding streams and budgets. For these and other reasons discussed more fully below, existing studies of the economic impact of opioids are of limited value in assessing local governments' costs. These recent studies provide a helpful picture of the burden of the opioid crisis on a "macro," or national, level, but translating those findings into meaningful, calculable amounts for any particular local government is much more challenging.

\section{A. Literature Review}

This Section describes existing studies of opioid-related costs, namely health care, law enforcement, and lost productivity, as well some statespecific research assessing the scope of the opioid problem and its incidence within certain industries, but not the particular costs borne by local governments. We begin with two widely cited nationwide studies, then turn to two state-level studies for comparison, and, finally, describe some data collected on Georgia specifically.

1. Florence et al., The Economic Burden of Prescription Opioid Overdose Abuse, and Dependence in the United States

One of the most widely cited opioid cost studies is Curtis S. Florence 
et al.'s 2016 study The Economic Burden of Prescription Opioid Overdose Abuse, and Dependence in the United States, 2013. ${ }^{220}$ The Florence study considered costs recorded in 2013 in three main areas: the healthcare system, criminal justice, and the workforce. ${ }^{221}$ The study considered costs incurred due to overdose and abuse/dependence by examining health care and treatment cost, criminal justice cost, and lost productivity. ${ }^{222}$

The total economic burden of the opioid crisis was "estimated to be $\$ 78.5$ billion." ${ }^{223}$ Over one-third of the total were excess health care costs caused by the opioid crisis, amounting to $\$ 28.9$ billion. ${ }^{224}$ Increased criminal justice costs due to the opioid crises were about $\$ 7.7$ billion. ${ }^{225}$ The estimated cost of reduced productivity in the workforce was \$20.4 billion. ${ }^{226}$ Of those costs, the study found that seventy-three percent of the cost of the opioid crisis was found in the nonfatal consequences while twenty-seven percent was attributed to fatalities. ${ }^{227}$ Moreover, "[a]pproximately one quarter of the cost is borne by the public sector in health care, substance abuse treatment, and criminal justice costs." 228 While those findings are significant regarding the scope of the problem and overall public cost impact, they say little about the costs borne by any single state's city or county.

Regarding methodology, Florence et al.'s data on the incidence of overdoses in 2013 came from the U.S. Centers for Disease Control and Prevention (CDC) WONDER database, which reports all deaths in the U.S. National Vital Statistics System, identified by the ICD-10 codes (T40.2-T40.4), coded as unintentional, intentional, and undetermined. ${ }^{229}$ The measure of prescription opioid abuse and dependence came from the 2013 National Survey on Drug Use and Health (NSDUH), capturing the U.S. civilian noninstitutionalized population ages twelve and older. ${ }^{230}$ NSDUH collects information on substance use and identifies "abuse and dependence based on the Diagnostic and Statistical Manual of Mental

220. Curtis S. Florence et al., The Economic Burden of Prescription Opioid Overdose, Abuse, and Dependence in the United States, 2013, 54 MED. CARE 901 (2016).

221. Id. at $902-03$.

222. Id.

223. Id. at 901 .

224. Id.

225. Id. at 904.

226. Id.

227. Id.

228. Id. at 901.

229. Id. at 902.

230. Id. 
Disorders, 4th edition (DSM-IV)."231 The NSDUH "also collects detailed data on health insurance coverage ... and ... demographic information" (e.g., sex and age). ${ }^{232}$ The authors used NSDUH data to assign "health care costs and lost productivity costs to abuse/dependence cases". 233

The study also used a "matched case-control design . . . to estimate the impact of prescription opioid abuse diagnoses on health care spending," using the "Truven Health MarketScan Research Databases for commercial, Medicaid, and Medicare health plan enrollees."234 The Truven Databases contain the pooled healthcare experience of enrollees in each type of health plan. ${ }^{235}$ For commercial and Medicare analyses, the study used a logistic regression model that "included age, sex (male/female), baseline health care costs, Charlson comorbidity index, region of patient residence,... and plan type... as independent variables." 236 The Medicaid analysis utilized "a logistic regression model" that included "age, sex, race, baseline health care costs, Charlson comorbidity index, Medicare eligibility, basis of eligibility, and plan type."237 The total cost included "inpatient and outpatient care and all prescription drugs." 238 Excess costs "were then multiplied by the relevant number of opioid abuse patients derived from the NSDUH for each insurance coverage category reported in the survey data." 239

The study acknowledged that there are other sources of payment for substance abuse treatment besides health plans; for example, the U.S. Department of Health and Human Services Substance Abuse and Mental Health Services Administration (SAMSHA) "block grants and private foundation funding." ${ }^{240}$ Florence et al. accounted for those additional sources of payment by "identifying non-insurance-based federal, state, local, and private expenditures" for substance abuse treatment and then multiplying those costs "by the share of drug abuse and dependence cases associated with prescription opioids in the 2013 NSDUH."241

With respect to criminal justice costs, the study considered four components: "(1) police protection, (2) legal and adjudication, (3)

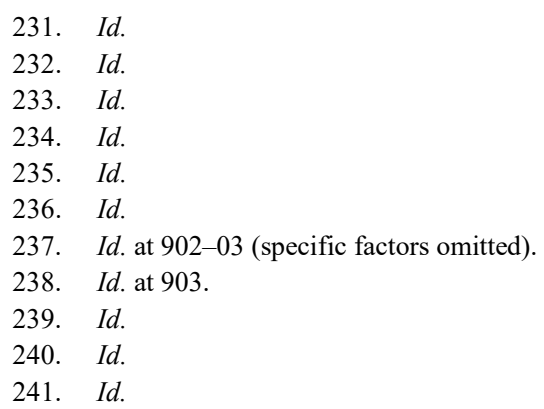


correctional facilities, and (4) property lost due to crimes." 242 Spending data on the first three components were obtained from the Justice Expenditure and Employment Extracts, 2012-Preliminary ${ }^{243}$ and "data on property lost due to crimes" was obtained from the Federal Bureau of Investigation's Crime in the United States, 2012. ${ }^{244}$ The study then calculated the ratio of these costs that were attributable to opioids in 2013 by looking to "the ratio of arrests for the components of police protection and legal and adjudication" costs, "the ratio of incarcerations for the correctional facilities component", and the "ratio for the component of property lost due to crimes". ${ }^{245}$

The study considered three components of lost productivity costs: "(1) premature death from prescription opioid abuse or dependence, (2) reduced productive hours for abuse/dependence, and (3) incarceration." 246 The cost of fatal opioid abuse or dependence was assessed by "entering the number of prescription opioid overdose deaths in 2013 into the Cost of Injury Reports application under CDC's WISQARS (Web-based Injury Statistics Query and Reporting System) cost module." ${ }^{247}$ The module "estimates the lost productivity of a fatal injury based on the sex and age of the decedent and the mechanism of injury." 248 The study then determined the costs based on "expected earnings for a person of the decedent's sex and age over the remaining expected lifespan." 249 For calculating lost productivity, the study estimated the average time spent in employment and household production and "estimated the value (including fringe benefits) of this time by age and sex category." 250 That value was then "multiplied by the percentage reduction in productivity attributable to drug abuse/dependence (17\% for males and $18 \%$ for females), and finally summed over values across all sex and age groups." 251 The prevalence of abuse/dependence cases "for each sex and age group [was] tabulated from the 2013 NSDUH" and then multiplied

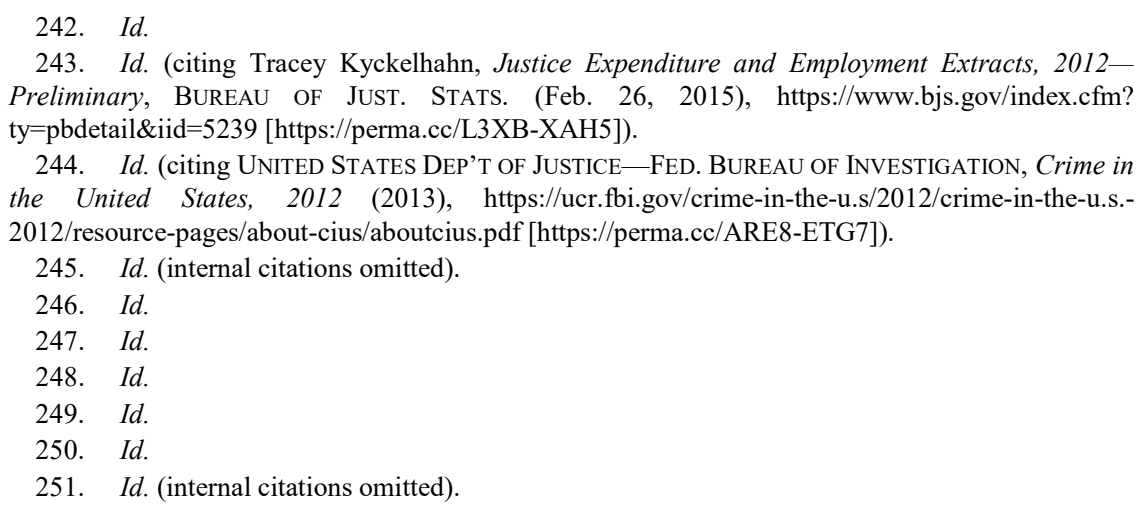


"by the corresponding per person annual production value of US population" (inflated to 2013 dollars). ${ }^{252}$ For calculating lost productivity due to incarceration, the study took "the number of inmates incarcerated for crimes attributed to prescription opioid abuse or dependence at federal, state, and local levels" and multiplied by the per person "annual production value of the US population inflated to 2013 dollars." 253

\section{U.S. Council of Economic Advisor's Report, The Underestimated Cost of the Opioid Crisis}

Another important study on opioid costs is the U.S. Council of Economic Advisor's (CEA) 2017 report, The Underestimated Cost of the Opioid Crisis. ${ }^{254}$ The CEA reached a much higher estimate of \$504 billion, which is six times higher than Florence et al.'s estimate, even when adjusted to 2015 dollars. ${ }^{255}$ The CEA expanded Florence et al.'s study and made efforts to take into account the following additional factors: (1) the worsening of the crisis since Florence et al.'s study; (2) the increasing role of heroin abuse in the crisis; (3) evidence suggesting that fatality statistics understate the number of opioid-related deaths; and (4) the value of lives lost beyond earnings losses. ${ }^{256}$ One particularly notable difference, the CEA's study included fatal and nonfatal measurements of heroin use, along with prescription opioid use, in evaluating the cost of the opioid crisis. $^{257}$

With respect to fatalities, the CEA

diverge[d] from the previous literature by quantifying the costs of opioid-related overdose deaths based on ... the "value of a statistical life' (VSL). Federal agencies routinely rely on VSL measures in health and safety settings when estimating the expected fatality risk-reduction benefits of a proposed regulation, policy, or program ... Such valuations are typically based on how individuals trade off wealth for reduced mortality risks. ${ }^{258}$

The CEA calculated the estimated VSL under four alternate

\footnotetext{
252. Id. (internal citations omitted).

253. Id.

254. The Council of ECON. Advisors, The Underestimated Cost of the Opioid Crisis (Nov. 2017), https://www.whitehouse.gov/sites/whitehouse.gov/files/images/The Underestimated Cost of the Opioid Crisis.pdf [https://perma.cc/3AWV-EEZD] [hereinafter CEA].

255. Id. at 1 .

256. Id. at $1-3$.

257. Id. at 1 .

258. Id. at 3 .
} 
assumptions, ultimately preferring an age-dependent assumption drawn from a 2003 study by Aldy and Viscusi. ${ }^{259}$ The age-dependent calculation assumes that individuals between twenty-five and forty-four years old "place the greatest value on fatality risk reduction," while those between ages eighteen and twenty-four, and forty-four and sixty-two, place lower values on risk reduction. ${ }^{260}$ Using that assumption, the CEA estimated total fatality costs of $\$ 431.7$ billion. ${ }^{261}$

To get there, CEA took the number of "officially reported opioidinvolved overdose deaths in the United States" in 2015 from the CDC WONDER Database - approximately 33,000 - and created a distribution of the deaths by age. ${ }^{262}$ Because recent research suggested that opioidrelated overdoses are underreported on death certificates, ${ }^{263}$ the CEA accordingly adjusted the number of deaths in 2015 , increasing the estimate to approximately $41,000 .{ }^{264}$ Using various possible alternate assumptions of VSL, the CEA estimated that the fatality cost of opioid overdoses ranged "from a low of $\$ 211.6$ billion to a high of $\$ 549.8$ billion." 265 The preferred age-dependent VSL assumption yielded an estimate cost of $\$ 431.7$ billion for opioid fatalities. ${ }^{266}$ This is because the epidemic's fatalities are concentrated in the age groups that have high valuations for risk reduction. ${ }^{267}$

With respect to nonfatal opioid misuse, the CEA calculated the costs in two steps: (1) First, CEA used Florence et al.'s "estimates to obtain a per-person measure of costs" of those who did not die within the year; (2) second, that per-person cost was multiplied by "the number of individuals with an opioid use disorder in 2015 . .."268 Accounting for inflation since 2013, the CEA estimated that the average individual with an opioid

\footnotetext{
259. Id. at 6 (citing W. Kip Viscusi \& Joseph E. Aldy, The Value of a Statistical Life: A Critical Review of Market Estimates Throughout the World, 27 J. RISK \& UNCERTAINTY 5 (2003)).

260. Id. at 5 .

261. Id. at 5-6.

262. Id. at 5 .

263. Id. at 6 (" $[\mathrm{R}]$ ecent research has found that opioids are underreported on death certificates... . [T]n 2014, opioid-involved overdose deaths were 24 percent higher than officially reported. We apply this adjustment to the 2015 data, resulting in an estimated 41,033 overdose deaths involving opioids. We apply this adjustment uniformly over the age distribution of fatalities.") (citing Christopher J. Ruhm, Geographic Variation in Opiod and Heroin Involved Drug Poisoning Mortality Rates, 53 Am. J. PreVEntive Med. 745 (2017), https://www.ajpmonline.org/article/S07493797(17)30313-6/pdf.

264. Id.

265. Id. at 6-7.

266. Id. at 6 .

267. Id.

268. Id. at 7 .
} 
disorder cost his/her community $\$ 30,000 .^{269}$ That estimate of the average cost then was applied to the 2.4 million individuals with opioid disorders in 2015 , estimating the total cost of nonfatal opioid misuse to be $\$ 72.3$ billion. ${ }^{270}$ The CEA, although using Florence et al.'s estimates in its calculations, applied them to both prescription and heroin use disorders. ${ }^{271}$ That divergence may result in the CEA's study "understat[ing] the cost of nonfatal consequences of heroin as criminal justice system costs may be higher for illicit drugs . . . than for prescription drugs." 272 But "only 14 percent of the 2.4 million individuals with an opioid use disorder in 2015 presented with a heroin use disorder in isolation; others either had a prescription opioid disorder or both disorders present." ${ }^{273}$ Thus, those individuals would have been accounted for in the Florence et al. study. ${ }^{274}$ Accordingly, the CEA did not believe that the total cost estimate was significantly biased. ${ }^{275}$

In sum, the CEA combined the estimated fatality costs and nonfatality costs to conclude that the total cost of the opioid crisis, including both prescription and illicit opioids, was between \$293.3 billion and \$622.1 billion. ${ }^{276}$ The preferred age-dependent VSL calculation resulted in the estimated total cost being \$504 billion. ${ }^{277}$ As noted above, that estimate is significantly higher than Florence et al.'s, as well as two earlier studies by Birnbaum et al. ${ }^{278}$ One, conducted in 2006, estimating costs for 2001, came to $\$ 11.5$ billion in 2015 dollars. ${ }^{279}$ The other, conducted in 2001, estimating costs for 2007, came to $\$ 61.5$ billion in 2015 dollars. ${ }^{280}$ Both Birnbaum et al. studies were limited to prescription opioids. ${ }^{281}$

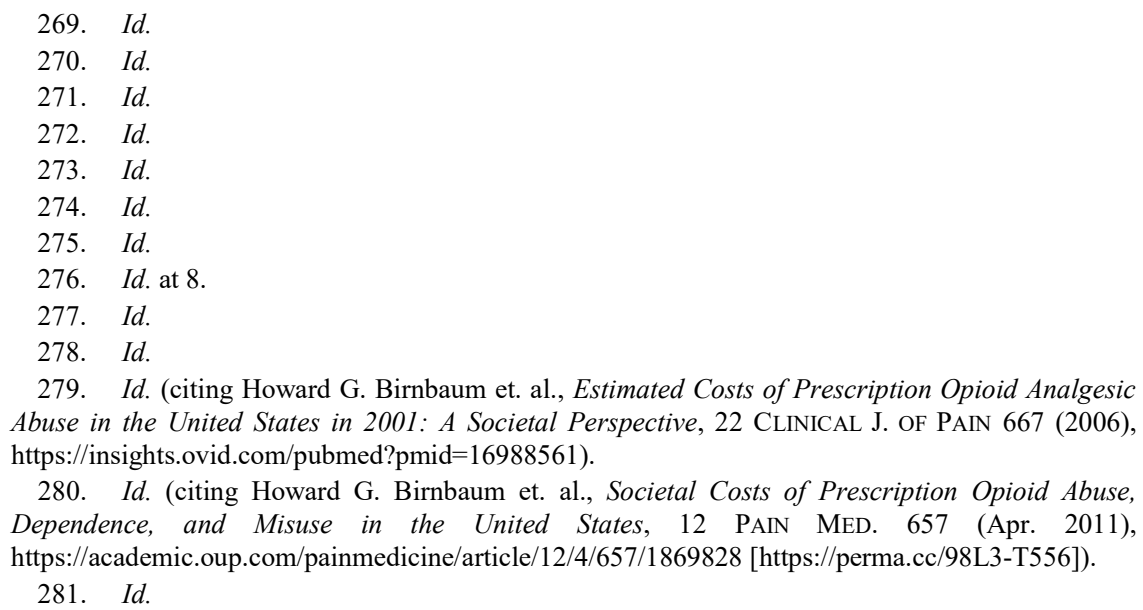

280. Id. (citing Howard G. Birnbaum et. al., Societal Costs of Prescription Opioid Abuse, Dependence, and Misuse in the United States, 12 PAIN MED. 657 (Apr. 2011), https://academic.oup.com/painmedicine/article/12/4/657/1869828 [https://perma.cc/98L3-T556]).

281. Id. 
3. Missouri Hospital Association and Hospital Industry Data Institute, Economic Costs of Opioid Epidemic in Missouri

More recently, Missouri and the Hospital Industry Data Institute (HIDI) conducted a study of opioid costs for a single state. The Economic Cost of the Opioid Epidemic in Missouri, published in January 2018, used the CEA's methodology with updated CDC mortality data to estimate the economic burden of the opioid crisis at the state level, focusing on Missouri in 2016. ${ }^{282}$

Missouri's fatality costs were "derived by applying age-dependent estimates of the [VSL] to the ... opioid overdose deaths for each age category from the CDC WONDER database." 283 Like the CEA's report, HIDI adjusted the measures on CDC WONDER database to reflect the estimated twenty-four percent underreporting of opioid deaths. ${ }^{284}$ HIDI's estimated nationwide economic costs of opioid-related fatalities came to $\$ 544$ billion in 2016, "compared to the CEA's fatality cost estimate of $\$ 431.7$ billion in 2015." 285 Thus, the study suggests "a 26 percent increase, which is largely explained by the 29 percent increase in opioid overdose deaths and 1.3 percent [U.S.] inflation between 2015 and 2016." 286

The CEA's nonfatality costs were derived from Florence et al.'s estimate that individuals with opioid abuse/dependence cost " $\$ 30,000$ per person in the form of reduced productivity, increased consumption of health care, law enforcement, and social services." 287 The most "significant" deviation from the CEA study was the used of state-level SAMSHA data on heroin use, rather than the CEA's data on both prescription and illicit opioid use. ${ }^{288}$ The SAMSHA data were preferable because the Missouri study sought to "estimate between-state variation in the economic burden of opioid use disorder". ${ }^{289}$ SAMSHA's surveygenerated data revealed that 882,000 American adults reported using heroin between 2015 and 2016, compared to the CEA's 2.4 million

\footnotetext{
282. See generally The Economic Cost of the Opioid Epidemic in Missouri, HoSP. InDUS. DATA INST. at 1-2 (Jan. 2018), https://www.mhanet.com/mhaimages/HIDIHealthStats/Feb2018Health Stats_Special_OpioidsEconomy.pdf [https://perma.cc/89AA-WZJG].

283. Id. at 3 .

284. Id.

285. Id.

286. Id.

287. Id. (citing Florence et al., supra note 220).

288. Id. at 3-4.

289. Id. at 3 .
} 
estimate. ${ }^{290}$ Although about two-thirds lower, the HIDI study noted that the nonfatality costs were just " 15 percent of the total economic costs of opioid use disorder in the CEA study." 291 As a result, HIDI's "estimated nonfatality costs in the U.S. totaled $\$ 27.3$ billion in 2016, compared to the CEA's estimate of $\$ 72.3$ billion in 2015." 292

Adding the fatality and non-fatality opioid-related costs, the HIDI study estimated the "total economic cost of opioid use disorder and overdose deaths . . to be $\$ 571.5$ billion in 2016," which was " 13 percent higher than the CEA's estimate of \$504 billion in 2015."293 Overall, the study concluded that the cost represented " 3.1 percent of the national GDP of \$18.5 trillion" for 2016. ${ }^{294}$

HIDI then calculated state-level costs in Missouri, estimating that the opioid epidemic produced $\$ 519$ million in nonfatality costs (considering only heroin use) and $\$ 12.1$ billion in fatality-related costs, for a total of $\$ 12.63$ billion in 2016, or " 4.22 percent of the state's total GDP." 295 That estimate placed Missouri "in the fourth quintile nationally," and the " 15 thhighest among the fifty states and the District of Columbia in terms of the total burden of opioid use disorder as a percent of overall economic activity." 296

\section{Massachusetts Department of Public Health, Opioid-Related} Overdose Deaths in Massachusetts by Industry and Occupation

Another state-level study that is potentially relevant to ours is a Massachusetts study of opioid-related deaths from 2011 to 2015. ${ }^{297}$ The Massachusetts Department of Public Health (MDPH) used information on state death certificates to explore different factors contributing to the differences in rates of fatal opioid overdose among workers in different industries and occupations. ${ }^{298}$ Based on ICD-10 codes, the MDPH identified death certificates for opioid-related overdose deaths. ${ }^{299}$

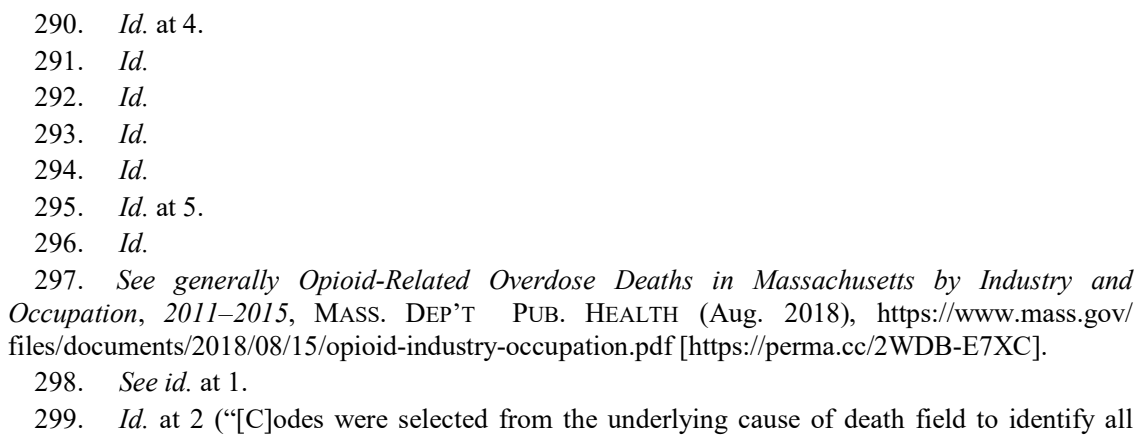


Additional death certificates were identified by searching the cause of death text fields for opioid-related terms for deaths, even if the death certificate did not receive an opioid-related death code. ${ }^{300}$ This process revealed "a total of 5,580 opioid-related overdose deaths in Massachusetts from 2011 to 2015." 301

Of those identified certificates, 191 were excluded because they belonged to out-of-state residents, 319 were excluded because their occupation was "homemaker," 208 were excluded because they "were unemployed or had never been employed," 199 were excluded because they "were unable to work due to disability or another reason," 160 were excluded because their occupation was "student," and 2 were excluded because they were children. ${ }^{302}$ Another "199 individuals were excluded because their death certificates" did not provide enough information to classify them according to their employment "industry or occupation." 303 That left 4,302 deaths that were usable for the study. ${ }^{304}$ The industries and occupations of the deceased were classified according to the North American Industry Classification System and the Standard Occupational Classification System respectively. ${ }^{305}$

The study found that "[t]he opioid-related death rate for those employed in construction and extraction occupation was six times the average rate for all Massachusetts workers." 306 "Construction and extraction workers accounted for more than $24 \%$ of all opioid-related deaths among the working population" studied. ${ }^{307}$ Ninety-seven percent of that population were employed in construction. ${ }^{308}$ The rate of opioidrelated deaths for workers in farming, fishing, and forestry "was more than 5 times the average rate for Massachusetts workers." 309 Seventy-four percent of those studied within this group worked in fishing occupations. ${ }^{310}$ "Other occupations with significantly higher than average rates of opioid-related deaths ... included: material moving occupations;

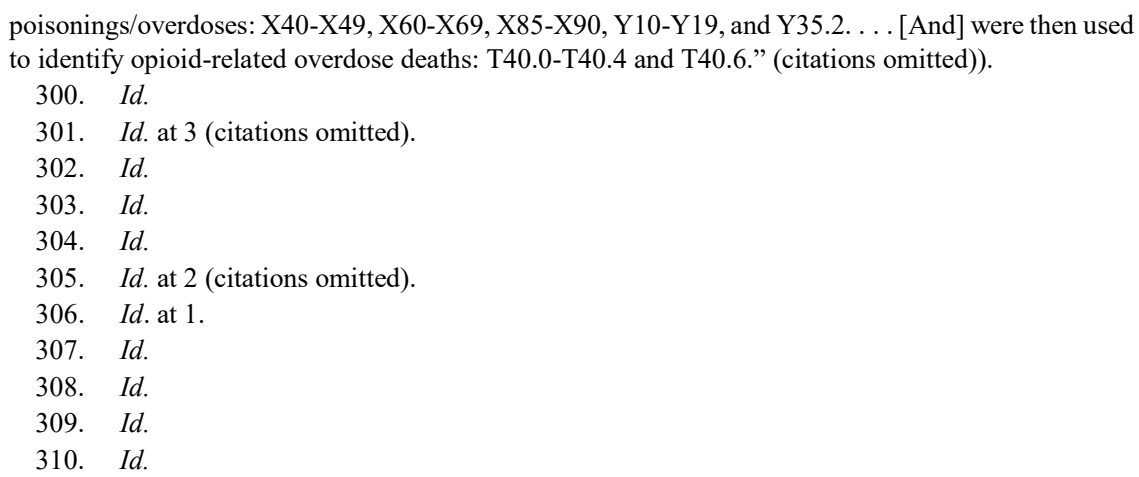


installation, maintenance, and repair occupations; transportation occupations; production occupations; food preparation and serving related occupations; building and grounds cleaning and maintenance occupations; and healthcare support occupations." 311

Analyzed based on sex of workers, the study found that occupations with higher-than-average rates of fatal opioid-related overdoses for men included farming, fishing, and forestry; construction and extraction; and material moving. ${ }^{312}$ While occupations with higher than average rates of fatal opioid-related overdose for women included healthcare support and food preparation and service. ${ }^{313}$

Overall, "the rate of fatal opioid-related overdose was higher among workers employed in industries and occupations known to have high rates of work-related injuries and illness," perhaps explained by the use of opioids to deal with "acute and chronic pain following work-related injury." 314 The study concluded that more research would be needed to characterize the contributions of such factors to opioid misuse and overdose. ${ }^{315}$ The study did not further correlate Massachusetts opioids deaths with costs, including lost productivity or other financial impacts.

\section{Georgia Studies on Opioid Impact}

Finally, two Georgia studies are potentially informative, yet still fail to capture the cost impact of opioids at the city or county level in any meaningful way. First, the Georgia Department of Public Health (DPH), Opioid Overdose Surveillance ${ }^{316}$ included a study of death certificates, similar to the Massachusetts study. DPH derived data of opioid and overdose-related deaths from "the death certificates of all deaths occurring in Georgia during 2016" that were in DPH's Vital Records. ${ }^{317}$ Drug overdoses included "prescription, over-the-counter, or illicit drugs." 318 DPH looked for death certificates with ICD-10 codes with opioids (prescription and illicit) as the underlying cause of death; those with ICD10 codes that had multiple cause-of-death codes (specifically T40.0-

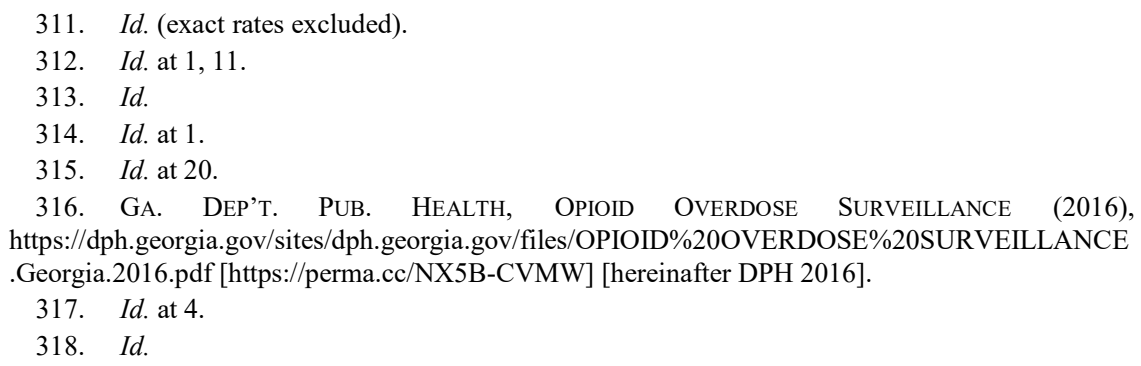


T40.4, T40.6); and those with any "cause of death text field" containing certain keywords (e.g. heroine, fentanyl, acetyl fentanyl, furanyl fentanyl, methadone, etc.). ${ }^{319}$ "Nonfatal overdose counts were derived from Georgia hospital discharge inpatient and [emergency department] visit data, and included all [emergency department] visits or hospitalizations occurring in a non-federal acute care hospital in Georgia... with a discharge diagnosis indicating acute drug overdose during 2016." ${ }^{320} \mathrm{DPH}$ looked for ICD-10CM codes as the principle diagnosis (T40.0X-T40.3X, $\mathrm{T} 40.60, \& \mathrm{~T} 40.69$ ) and a sixth character ("1-4, and a 7 th character of A or missing"). ${ }^{321}$ From this data, the study concluded that "[f]rom 2010 to $2016, \ldots$ opioid-involved overdose deaths increased in Georgia by $117 \%$." 322 Moreover, in 2016 there were 2,895 emergency department visits related to opioid overdoses, and 2,499 inpatient hospitalizations related with opioid overdoses. ${ }^{323}$

2016 is the only completed study, but DPH has collected similar data for $2017^{324}$ and part of $2018,{ }^{325}$ including a county-level data on fatal and nonfatal overdoses for 2017.326 While these data are salient, their usefulness in estimating city or county-level costs are limited for reasons explained more fully below. ${ }^{327}$ The hospital emergency department and acute care costs are not particularly relevant because cities and counties generally do not pay for hospital services, other than under limited circumstances, discussed more fully below. ${ }^{328}$ Overdose mortality data are very helpful in deriving coroner costs associated with opioid-related deaths but are harder to translate into other meaningful local government costs.

Second, the Substance Abuse and Research Alliance (SARA) 2017

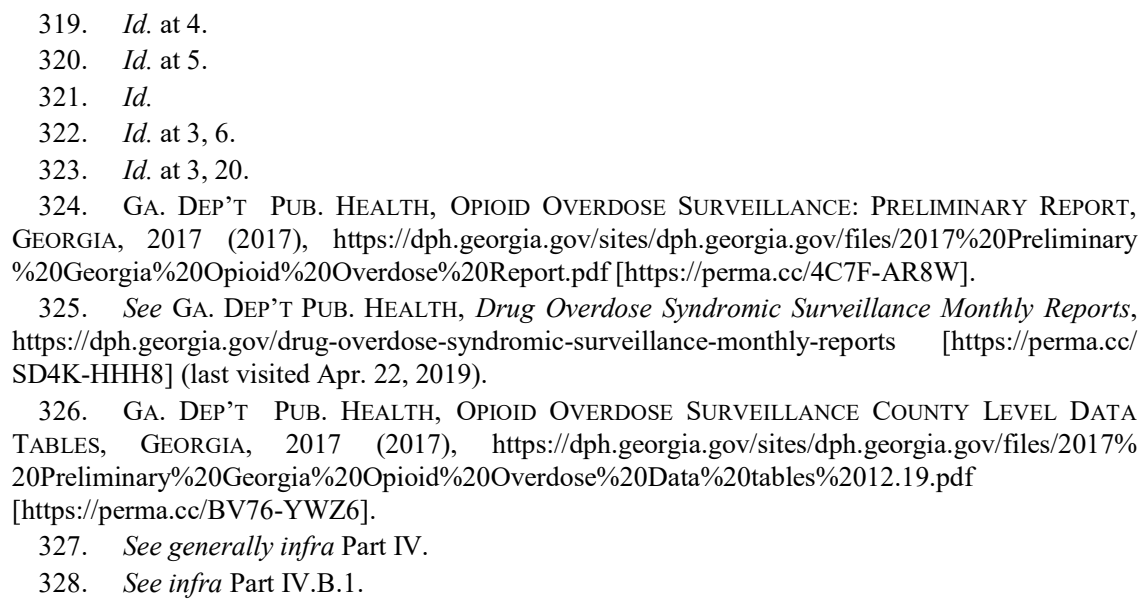


White Paper, Prescription Opioids and Heroin Epidemic in Georgia, provides a comprehensive overview of the scope of the problem in Georgia, with limited mention of costs. ${ }^{329}$ SARA is a program of the Georgia Prevention Project. ${ }^{330}$ The study was initiated "in April of 2016 . . . to assist the Georgia State Senate Study Committee on Opioids and Heroin." 331 SARA found that 900 , or $68 \%$, of the 1,307 drug overdose deaths in Georgia in 2015 were due to opioid overdoses including heroin. ${ }^{332}$ "Further," Georgia experienced "a statistically significant increase in the drug overdose death rate... from 2013 to 2014, and overdose deaths tripled between 1999 and 2013." 333 Georgia is "[a]mong the top 11 states with the most prescription opioid overdose deaths," and " 55 of Georgia's 159 counties had higher drug overdose rates than the U.S. average in 2014." 334 Georgia's rural counties are especially impacted. ${ }^{335}$ "Sixty percent of the 55 counties with drug overdose rates higher than the national average are located in rural areas." 336 Those areas already struggle to provide access to substance use disorder treatment, including medication assisted treatment (MAT). ${ }^{337}$ SARA estimated that "twothirds of all counties in Georgia," and more than three-quarters of rural counties, "have limited or no access to an evidence-based practice for opioid use disorder." 338

Regarding costs, the study briefly noted that "[ $\mathrm{t}]$ he economic burden of prescription opioid overdose, misuse and disorders in the U.S. is estimated at $\$ 78.5$ billion in 2013 with over one third of this amount coming from increased health care and substance use treatment costs (\$28.9 billion)." 339 The study went on to note that "[t] he health care costs associated with opioid misuse in Georgia alone were estimated at \$447 million in 2007 with estimated per-capita costs at $\$ 44$." 340 That amount, according to some estimates, represents an eighty percent increase since

\footnotetext{
329. Substance Abuse Res. Alliance, Prescription Opioids and Heroin Epidemic in GEORGIA—A White PAPER (2017), http://www.senate.ga.gov/sro/Documents/StudyCommRpts/ OpioidsAppendix.pdf [https://perma.cc/WL6L-FYPS] [hereinafter SARA 2017].

330. Id. at 3 .

331. Id.

332. Id. at 5 .

333. Id.

334. Id.

335. Id.

336. Id.

337. Id. at 5,23 .

338. Id. at 5 (noting that " 77 percent of rural counties in Georgia have limited or no access to an evidence-based practice for opioid use disorder").

339. Id. at 7 .

340. Id.
} 
2007. ${ }^{341}$ "Hospitalizations related to opioid use and misuse in Georgia also have skyrocketed, from about 302,000 in 2002 to about 520,000 in 2012." 342 Moreover, SARA suggested that inpatient care costs "more than doubled" from 2002 to 2012, "rising to \$15 billion in 2012."343 Again, even accepting the accuracy of those reports, the figures do little to capture city- and county-level costs associated with the opioid epidemic. For local government plaintiffs to demonstrate damages in the litigation, or even for other local governments to develop meaningful budgets and other plans to address it, more specific cost estimates are needed.

\section{B. Limits of Existing Cost Studies for Assessing Local Government Costs}

The aforementioned research, while helpful in understanding the macro-impacts of opioid abuse, ultimately do little to help Georgia local governments assess their specific costs in dealing with this problem. First, at least for purposes of litigation, local governments are trying to measure only direct, rather than direct and indirect, costs. Second, estimates based on national averages cannot be applied to individual cases. The following discussion briefly explains the limits of the existing studies, highlighting the need for our project.

Florence et al., CEA, and HIDI all estimate the cost of the opioid epidemic from loss of life, which represents the largest impact of the crisis. Those costs, however, are not direct losses for local governments. The direct costs from opioid deaths for a local government would be potential lost sales and property tax revenue, i.e., the deceased person not purchasing taxable goods. Theoretically, the government could estimate that lost sales tax income by using data from the Bureau of Labor Statistics' Consumer Expenditure Survey. ${ }^{344}$ That consumer spending data, however, represents average spending nationally or for a region of the county; thus, again it reveals little about any individual city or county. Additionally, local governments would be making assumptions about the potential earnings and expenditures of specific persons who died from opioid overdoses in their jurisdictions and the residential duration of the deceased in their respective communities. A local government would likely have trouble verifying any purported lost sales tax based on those vague assumptions.

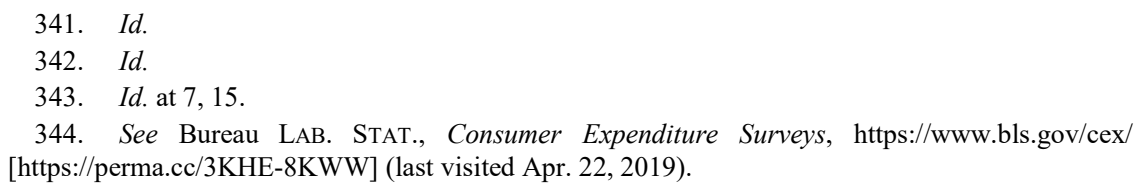


Foregone or diminished property taxes from drug overdoses are even less likely. Property taxes would be lost only if, first, the person who died from an overdose owned property, and, second, the owned property declined in value because the person died. Assuming that the deceased were a property owner, there is no reason to think that simply because a person died of an opioid overdose that her property would be of less worth any more than if a person died of some other cause, such as a heart attack or cancer. Property taxes could be adversely affected by the opioid crisis if a neighborhood experienced an overall decline in desirability, such as having significant blight or high numbers of home foreclosures. ${ }^{345}$ Even so, it would be difficult to attribute those impacts to opioids alone. Those same neighborhood challenges are more typically the result of high unemployment and other socioeconomic challenges which may contribute to higher rates of opioid abuse but cannot be attributed to the drug problem in isolation. ${ }^{346}$ A local government would have difficulty determining whether a neighborhood is in decline because of opioid abuse or these other societal problems, which are often the antecedents to widespread drug addiction.

Florence et al. also considered the economic cost of general lost productivity from opioid addiction, such as absenteeism and persons being incarcerated. Again, local governments would not be able to consider lost productivity of its entire population as direct costs. Lost productivity is different from the direct costs of incarceration which are considered in our study.

The Florence et al., CEA, and HIDI studies measure the direct costs to law enforcement and the courts from opioid addiction. To be sure, local governments bear significant portions of those costs, including time of police officers, sheriff deputies, jails, and courts. Nonetheless, methodological problems prevent local governments from applying the averages used in those studies to estimate law enforcement costs. Nonetheless, the averages used in those studies to estimate law enforcement costs cannot be applied to individual local governments for their individual cost estimations because of methodological problems. Namely, national averages, such as the percent of property crime associated with drug use, are based on many inputs. Any particular local

345. See, e.g., Press Release, Ohio House of Representatives 133rd Gen. Assembly, Bipartisan "Blight Bill" Would Protect Neighborhoods from Dangerous Properties, Lawmaker Says (Jan. 26, 2018), http://www.ohiohouse.gov/adam-c-miller/press/bipartisan-blight-bill-would-protect-neighbor hoods-from-dangerous-properties-lawmaker-says [https://perma.cc/TJZ7-MVDJ].

346. Nabarun Dasgupta et al., Opioid Crisis: No Easy Fix to Its Social and Economic Determinants, 108 AM. J. Pub. HeALTH 182, 182-84 (Feb. 2018), https://www.ncbi.nlm.nih.gov/ pmc/articles/PMC5846593/pdf/AJPH.2017.304187.pdf [https://perma.cc/MF67-YH35]. 
government may or may not be similar to the national average because of variations in community income, unemployment, major industries, and other factors.

The MDPH study that examined industries with higher rates of opioid addiction offers interesting information, but does not help local governments estimate their direct expenditures due to opioid abuse. Rather, this study appears most helpful in understanding potential causes of opioid addiction and offering insights for focused drug abuse prevention education and other interventions in certain industries. In communities with industries associated with higher rates of opioid addiction, local governments could direct efforts to work with those industry and union leaders to educate employees about potential opioid addiction and employ other targeted prevention and treatment efforts.

Since the MDPH study did not indicate that local government employees experience a higher rate of opioid addiction, the study is not instructive on city or county human resources costs for public employees' opioid use disorders. The study does not suggest particularly pronounced direct costs on local governments as an employer in terms of medical and substance abuse treatment, or high employee attrition or lost productivity. Even assuming opioid addiction among employees were an issue for a local government, the MDPH methodology does not help to quantify costs. The local government human resource department still would need to pull employee health records based on ICD-10 $\operatorname{codes}^{347}$ and apply other methodologies discussed below. ${ }^{348}$

Florence et al., CEA, HID, DPH 2016, and SARA 2017 all look at health care costs associated with opioid addiction. Those costs, while a significant component of the epidemic, largely are not applicable to cities and counties in Georgia because they generally do not pay for hospital services, other than under limited circumstances, including gratuitous uncompensated care grants to safety net hospitals, city and county employee health costs, and prisoner medical expenses at the local hospital. We unpack the various health care expenditures more fully in Part IV.

The overdose mortality data provided in the Georgia studies, DPH 2016, and SARA 2017, may be helpful to local governments in estimating coroner costs, which are somewhat standardized, but are harder to translate into other meaningful cost estimates.

347. See Using International Classification of Diseases (ICD) Codes to Assess Opioid-Related Overdose Deaths, Substance Abuse \& Mental Health Servs. Admin. Ctr. for the APPLICATION OF PREVENTION TECH., https://mnprc.org/wp-content/uploads/2019/01/using-icd-10codes-to-assess-opioid-related-overdose-deaths.pdf [https://perma.cc/J838-9ETE] (last visited Apr. 22, 2019)

348. See infra Part IV.A. 
In sum, the applicability of these existing studies on the cost of opioid addiction to local governments for calculating direct cost estimates is either extremely limited because of the generalizations used in the research or simply because local governments do not bear the burden of the expense, such as health care.

\section{LOCAL GOVERNMENT OPIOID COST STUDY}

With that background on the opioid litigation and existing studies estimating macro-level costs and state-level incidence of opioid use disorder, we turn now to describing our study methodology and findings. The goal of the study was not to derive quantifiable hard data on the three counties' opioids costs or to create damages claims that would be admissible in court. Rather, we sought to reality test our existing understanding of local government operations, budgeting, and planning to better understand where the costs of this epidemic might appear. We looked beyond the Florence et al. categories of health care, law enforcement, and lost productivity to capture a broader array of potential local government costs. Moreover, we sought on-the-ground experiences and anecdotes from department heads, rather than extrapolating from statistical studies, to more fully understand the financial impact of the opioid epidemic at the local level. Our findings may be useful to MDL and other litigants but also other local governments seeking to get a better grasp on the effect of this issue on their operations so that they can make appropriate budget and planning decisions going forward.

\section{A. Methodology}

Our study consisted of unstructured qualitative interviews with two dozen identified local government department heads in three Georgia counties, as well as a handful other governmental and non-profit organizations' representatives, suggested by other interviewees through informal snowball sampling. In each of the three counties, we made initial contact with the County Administrator, who is the chief executive officer of the county responsible for the day-to-day operations of the county. After the County Administrators agreed to participate in our study, we asked them to contact the relevant department heads, alerting them to our project and asking for their cooperation. With that introduction, we then contacted and requested interviews with administrative heads of the following units: Coroner, Law Enforcement (Police, Drug Enforcement Authority (DEA)), Correctional Institute (typically run by the Sheriff), Court Administration (a local governmental unit overseeing various 
courts), Parks and Recreation/Leisure Services, Libraries, Treatment Services, Human Resources, Finance/Budget, Hospitals, Emergency Communications (911), Emergency Medical Services (EMS), Code Enforcement, Solicitor General (Prosecutor), Fire, Solid Waste, and Community Services. We also reached out to representatives of the local private, non-profit hospitals and, in one case, the school superintendent.

We selected the three counties by the mostly unscientific method of localities that were plaintiffs in the opioid MDL and where we had preexisting contacts with the County Administrators or other officials and, thus, a better chance of response and cooperation. The three Georgia counties surveyed were Athens-Clarke (where the University of Georgia is located, and which has a combined city-county government), ${ }^{349}$ Hall (County Seat: Gainesville), ${ }^{350}$ and Decatur (County Seat: Bainbridge). ${ }^{351}$ Subject to the opportunities above, the three counties were chosen for their diversity: Decatur County is very rural, located in southwest Georgia. Athens-Clarke and Hall are in northeast Georgia; the former is fairly urban/suburban while the latter is mix of urban and rural. In total, we interviewed twenty-six local government administrators in the three counties and five non-local-governmental administrators, including the Decatur County school superintendent; the executive director of Decatur County's private, nonprofit hospital; the director of government affairs for the private nonprofit health system serving Hall County; a representative of the private EMS company that serves Decatur County; and a representative of the drug treatment center for Hall county, for a total survey of thirty-one people. Each interview lasted from thirty minutes to one hour. Most interviews were conducted by phone, although several of the Athens-Clarke County interviews were in-person.

The officials with whom we spoke represented services that we believed would experience direct, indirect, or even intangible or future costs related to opioid use. In describing the limits of existing opioid financial impact studies above, we focused on direct costs, which would be most relevant to the litigation. For purposes of this study, however, we wanted to collect as much information as possible, given the multiple aims. Thus, we included those services that are typically mentioned when considering the cost of opioids-jails, courts, fire departments, EMS, and hospitals - but also those that have received less attention such as libraries,

\footnotetext{
349. Athens-Clark County Unified Gov't., https://www.athensclarkecounty.com [https://perma.cc/VF2V-GDLB] (last visited Apr. 22, 2019).

350. Hall County Georgia, https://www.hallcounty.org [https://perma.cc/4VLE-5K4H] (last visited Apr. 22, 2019).

351. Welcome to Decatur County Georgia, https://www.decaturcountyga.gov [https://perma.cc/TUW9-SZ4Q] (last visited Apr. 22, 2019).
} 
parks, solid waste, human resources, and code enforcement. In total, our interviews include representatives from seventeen different local government or non-profit services.

We were fairly strict in our identification of truly local government costs, which meant that we did not collect information about some costs alleged repeatedly in the complaints. For example, the complaints allege costs associated with child care for children of parents suffering opioidrelated addiction or incapacitation. ${ }^{352}$ Those costs, however, typically do not fall on local governments in Georgia. The Division of Children and Family Services (DCFS) and foster care are state-funded ${ }^{353}$ (aside from some targeted local programs, captured elsewhere in our study). Likewise, school districts, which could incur costs associated with children of opioid-affected parents, are separately funded by local property taxes and a state supplement to underfunded counties; thus, school districts are not part of city and county government budgets. ${ }^{354}$ The complaints also alleged opioid-related medical treatment for both opioid-addicted babies and adults. ${ }^{355}$ We did speak to hospitals, even though a very small fraction (if any) of their revenue may come from local governments, such as where localities have expressly granted indigent care funds to safety net hospitals. $^{356}$ Some community hospitals operate under state law ${ }^{357}$ allowing the issuance of revenue bonds or certificates to fund construction or other projects. ${ }^{358}$ But, like school districts, hospital authorities are separate legal and budget entities. Otherwise, Medicare (federal), Medicaid (state and federal), and private (insurers or charity) would be paying for such treatment. With respect to the complaints regarding opioid-affected babies and NAS, ${ }^{359}$ the bulk of neonatal intensive care unit

352. See supra note 14.

353. Ga. Dep't of Human Servis., Joint Appropriations Committee Presentation Fy 2016 AMENDED AND FY 2017 GENERAL BUDGET 20-28 (Jan. 19, 2016), http://dhs.georgia.gov/ sites/dhs.georgia.gov/files/AFY16\%20and\%20FY17\%20Budget $\% 20-\% 20$ Joint $\% 20$ Approriations\% 20Committee\%20Presentation\%20as\%20of\%201-19-16.pdf [https://perma.cc/AHX4-3F75]; Melissa Johnson, Georgia Human Services Budget Primer for State Fiscal Year 2018, GA. BudGET \& POL'Y INST. (July 12, 2017), http://gbpi.org/2017/georgia-human-services-budget-primer-state-fiscal-year2018/ [https://perma.cc/6UCL-4RUP].

354. Elton Davis \& IsABel Ruthotto, Ctr. For State \& Local Fin., Financing Georgia’s SCHOOLS: A 2015 BRIEFING 12 (Oct. 20, 2015), http://cslf.gsu.edu/files/2015/10/Financing-GeorgiasSchools_October-2015.pdf [https://perma.cc/Z46K-K5WX].

355. See supra note 14.

356. See, e.g., Indigent Care, FLOYD STRAIGHTFORWARD, http://floydstraightforward.org/ relevant-topic/indigent-care/ [https://perma.cc/A2XP-56JX] (last visited Apr. 22, 2019) (noting that a number of counties do receive local government funding, but Floyd County does not).

357. GA. CODE ANN. § 31-7-72 (West 2010).

358. GA. CODE ANN. § 31-7-78 (West 2010).

359. See supra note 14. 
costs for infants, as well as other emergency room and inpatient costs of treatment, would fall on hospitals ledgers, with minimal to no city or county funding. Likewise, local public health departments in Georgia are state funded. ${ }^{360}$

At the same time, we cast a wider net than the damages alleged in the lawsuits, seeking to identify not only documented costs associated with opioids but the full range of past and potential future financial impacts of this crisis. Thus, we imagined law enforcement costs associated with not only drug crimes and overdoses but also related crimes (shoplifting, theft, housing code violations). In addition, it is conceivable that libraries will be managing indigent, impaired, or even overdosing clients as places of public access. ${ }^{361}$ We included parks and leisure to capture costs associated with homeless camps and needle clean-up. ${ }^{362}$ Solid waste was included because of the possibility of needles or other opioid-related contaminants ending up in wastewater and sewage treatment plants. ${ }^{363}$ We ended up not interviewing any representatives of those departments, however, after anecdotal reports that any such problem in Georgia was nascent at best. Likewise, we considered reaching out to local government planning departments to assess potential lost opportunities for economic development, but, again, aside from anecdotes, there seemed little specific data to report, at least at this time. ${ }^{364}$ Because of the open-ended nature of our interviews, we also discovered other potential opioid-related costs that we had not previously identified.

360. GA. DEP'T OF PUB. HEALTH, http://georgia.gov/agencies/georgia-department-public-health [https://perma.cc/3A6S-SXL2] (last visited Apr. 22, 2019).

361. See Trisha Noack \& Roberta Koscielski, Peoria Public Library, How the Opiate Epidemic Came to the Library, 36 ILL. LIBR. Ass'N REP. 4, 4 (Aug. 2018), https://www.ila.org/ content/documents/reporter_0818.pdf [https://perma.cc/VMV4-BYNM].

362. See Gigen Mammoser, Opioid Epidemic Contributing to the Problem of Used Needles Littering Streets, Parks, Beaches, HEALTHLINE (Aug. 1, 2017), http://www.healthline.com/healthnews/used-needles-littering-streets-parks-beaches [https://perma.cc/U44E-QAJK].

363. See Susan Scutti, Mussels in Washington's Puget Sound Test Positive for Opioids, Other Drugs, CNN (May 25, 2018, 9:15 PM), https://www.cnn.com/2018/05/25/health/mussels-opioidsbn/index.html [https://perma.cc/2XRR-WE9L]. An analysis of city sewage can provide useful information for public health epidemiology and intervention. See Keridwen Cornelius, Sewage Is Helping Cities Flush Out the Opioid Crisis, SCIENTIFIC AMERICAN (May 25, 2018), https://www.scientificamerican.com/article/sewage-is-helping-cities-flush-out-the-opioid-crisis/ [https://perma.cc/DK35-ZAXD].

364. See, e.g., Stephen Fowler, The Cost of Opioid Addiction Is More Than Dollars and Cents, Ga. Pub. BRoAdCASTING (Aug. 29, 2017), http://www.gpbnews.org/post/cost-opioid-addictionmore-dollars-and-cents [https://perma.cc/XF5D-83CF] (discussing the economic effects of opioid abuse, such as "unfilled jobs and failed drug tests."). 


\section{B. Findings}

We predicted that identified costs would fall into one of three categories: (1) "easy," readily identified opioid-related costs that cities and counties already are tracking; (2) "medium," potentially identifiable opioid-related costs that cities and counties could track if given the tools and resources (e.g., spreadsheets, templates, or additional data collection fields or information feedback loops); and (3) "hard," indirect and intangible costs that are real but very difficult to quantify other than on a macro level. As it turned out, we found relatively few categories of "easy" costs; a larger bucket of "medium" costs; and an indefinite number of "hard" costs.

Those results suggests that local government plaintiffs may be challenged to demonstrate damages for purposes of the MDL lawsuit or settlement. Indeed, early indications from the MDL suggest that the task has been harder than expected, with at least one ninety-day extension already granted on the Government Plaintiff Fact Sheet, docketed on June 19, 2018. ${ }^{365}$ That discovery request calls for extensive, detailed disclosures all dating back ten years, including a much longer list of officials, ranging from mayors and councilmembers, to wardens and fire chiefs; annual budgets and actual expenditures for each category of damages claimed; claim-specific information, including each doctor and pharmacy that has been the target of a law enforcement or administrative investigation; number of overdose deaths and drug(s) involved; and every medical insurance plan or carrier, behavioral health carrier, workers compensation program, pharmacy benefit manager and other third-party administrator. ${ }^{366}$ The Fact Sheet also calls for supporting documents, including dispensing, prescribing, and distribution records, city council, county commission, and county health commission meeting minutes, again dating back ten years. ${ }^{367}$

The original ninety-day deadline for this production expired on September 18, 2018 (just a few days before this live symposium was held), but was extended for another ninety days, until December 17, 2018, suggesting that response was perhaps more challenging for government plaintiffs than initially anticipated. ${ }^{368}$ Further extensions were granted to

365. Fact Sheet Implementation Order, In re Nat'1 Prescription Opiate Litig., No. 17-2804 (N.D. Ohio June 19, 2018), ECF No. 638.

366. Id.

367. Id.

368. Order on Discovery in Track One Cases, and Amending Prior Orders at 7, In re: Nat'l Prescription Opiate Lit., No. 17-MD-2804. 
various localities affected by natural disasters, including fires in California and hurricanes on the East and Gulf Coasts. ${ }^{369}$ As the case proceeds, the plaintiffs may find that their participation is not costless, data is difficult to collect, and the demonstrable costs for any particular locality are modest. As just one indication, a local government lawsuit filed in Connecticut state court was dismissed on standing grounds because the city plaintiffs could not demonstrate cognizable injury. ${ }^{370}$ Thus, our local government cost study remains highly salient as it relates to the litigation specifically, and local government planning more generally.

Our findings confirm the suggestion above that local governments will face significant challenges in trying to fully capture all service costs associated with the opioid epidemic. That said, local governments should be able to quantify some direct costs, assuming multiple funding streams (federal, state, local, and private) can be disaggregated. In terms of how to determine costs, the primary challenge will be tracking service effort. How much of a provided service was directly or indirectly related to opioid use? Once service effort is known, calculating costs from that effort should be relatively straight forward, such as total hourly cost of employees' time, or better yet, cost per service episode that involved opioids.

Data management is also a critical factor in a local government's ability to track costs. Resource and personnel limits alone create significant challenges for local government plaintiffs to respond to the detailed MDL Fact Sheet or other inquiries. Those governments that have had the resources and interest in tracking services, such as creating a database for each prisoner that includes the reason for arrest in a searchable format, may have an easier time researching current and past opioid-related service costs. Smaller communities often translate to rural and poorer local governments, which typically lack financial resources to create and staff to manage sophisticated data management systems. Accordingly, we anticipate that those communities will face the greatest difficulty tracking cost data. Unfortunately, often it is these poorer communities that are most severely impacted by the opioid epidemic as a

369. Motion for Extension of Time to Respond to Plaintiffs' Fact Sheets on Behalf of Ctys. Affected by Recent Nat. Disasters, In re: Nat'l Prescription Opiate Lit., No. 17-MD-2804.

370. Connecticut Judge Dismisses Claims Against Opioid Manufacturers, FDA NEws (Jan. 18, 2019), https://www.fdanews.com/articles/189910-connecticut-judge-dismisses-claims-againstopioid-manufacturers [https://perma.cc/NWR6-ZRMT]; Paul Schott, Judge Dismisses Local CT Lawsuits Against Purdue Pharma, STAMford Advoc. (last updated Jan. 9, 2019, 5:57 PM), https://www.stamfordadvocate.com/business/article/Judge-dismisses-local-CT-lawsuits-againstPurdue-13521470.php [https://perma.cc/ZB4Y-VG7Q]. 
percentage of population or aggregate community impact. ${ }^{371}$

It is important to note that opioid lawsuits address only direct damages, those that can be quantified. ${ }^{372}$ Governments will not be able to recoup indirect costs such as those related to the long-term impacts on a child whose parents are addicted and thus may be neglected. States, in separate lawsuits, ${ }^{373}$ may be able to track and recoup costs related to foster care and other services but not the child's lost potential caused by the trauma that she experiences. Governments cannot measure the lost economic growth and tax dollars from companies that choose not to be located in a community because of concerns about not having an able workforce. Moreover, local governments will not be able to recover the opportunity costs from providing services for opioid-related issues. We turn next to describing the three categories of costs - easy, medium, and hard to quantify-identified through our study.

\section{Easy to Quantify}

We categorize opioid-related costs as "easy" to track and calculate when existing tracking systems would readily identify opioids as being a reason for the service effort. In most cases, that means there is an existing, extrinsic reason to track persons who use or sell opioids, or the particular cost is opioid-specific, such as costs associated with the opioid overdose drug, naloxone (or Narcan). ${ }^{374}$ For local government accounting purposes, the need to correlate expenditures with any particular individual receiving

371. See SARA 2017, supra note 329, at 5 (regarding opioid impact in rural Georgia); Drug Overdose in Rural America, CDC, https://www.cdc.gov/ruralhealth/drug-overdose/ [https://perma.cc/ 5TDJ-UF4X] (last reviewed Oct. 19, 2017).

372. See, e.g., Gov't Plaintiff Fact Sheet, In re: Nat'l Prescription Opiate Lit., No. 17-MD-2804 (requesting information on budget and expenditures, suspicious pharmaceutical prescriptions, and opioid-related meeting agendas).

373. See supra notes 79-81 and accompanying text (discussing state attorney general lawsuits); see also Allison Sherry, Opioid Crisis Is Sure to Be Factor in the Campaign for State Attorney General, COLO. PUB. RADIO (July 10, 2018), http://www.cpr.org/news/story/opioid-crisis-is-sure-tobe-factor-in-the-campaign-for-state-attorney-general [https://perma.cc/V8MJ-4TRE]; Press Release, Office of Attorney Gen. Chris Carr, Carr Announces Lawsuit Against Opioid Manufacturers and Distributors (Jan. 3, 2019), https://law.georgia.gov/press-releases/2019-01-03/carr-announceslawsuit-against-opioid-manufacturers-and-distributors [https://perma.cc/8GCA-6N34].

374. See generally Opioid Overdose Reversal with Naloxone (Narcan, Evzio), NAT'L INST. ON DRUG ABUSE (last updated Apr. 2018), https://www.drugabuse.gov/related-topics/opioid-overdosereversal-naloxone-narcan-evzio [https://perma.cc/3DC8-DNB5] (last visited Apr. 22, 2019) (describing Naloxone and how it is administered); Surgeon General's Advisory on Naloxone and Opioid Overdose, U.S. DEP'T OF HEALth \& HuMAn SERVS., https://www.surgeongeneral.gov/ priorities/opioid-overdose-prevention/naloxone-advisory.html [https://perma.cc/8PT6-XNZJ] (last visited Mar. 31,2019) (stressing the importance of the availability of Naloxone to assist in preventing overdoses). 
the services - much less for discrete indications - is relatively rare. For the most part, government is in the business of providing public goods to a population, not in the business of providing fee-for-service benefits to particular individuals, as explained more fully below. ${ }^{375}$ As a result of those features of local government management and accounting, the task of quantifying opioid-related costs turns out to be harder than we expected. The category of easy-to-quantify costs includes court administration fees; coroner investigations; naloxone; some medical care costs, including EMS, services to city and county employees, and indigent care grants; and grants or other spending earmarked for opioid treatment or related issues.

One set of costs that should be fairly easy to track are those associated with court administration. Courts have an extrinsic reason to correlate expenditures with opioids; namely, court administrators routinely track cases with the associated criminal codes, which indicate the nature of the crime and illicit substance involved. ${ }^{376}$ Thus, opioid services are known through the charges against the defendant. For example, the AthensClarke County Clerk of the Superior Court ${ }^{377}$ explained that she inputs a variety of information into her docket management system for each defendant, including the type of Georgia criminal code violation. ${ }^{378}$ To find opioid-related dockets, she just has to search the specific code number. ${ }^{379}$ Thus, we could derive a fairly reliable cost estimate for the court's opioid-related services.

Starting with those data entries, we could determine the percentage of criminal cases related to opioids. Hypothetically, let's suppose the court's opioid-related effort is ten percent. Second, we would determine the percentage of court administration total costs that are related to criminal cases. Suppose that forty percent of the court's administrative staff are dedicated to criminal cases (hypothetically, two of the five total staff). Then, the department's total operating budget is multiplied by forty percent, resulting in a criminal case budget. Forty percent of a hypothetical budget of $\$ 500,000$ equals $\$ 200,000$. That $\$ 200,000$ portion

375. See infra note 439 and accompanying text (discussing public goods and limits on the benefits-received model of local government service delivery).

376. GA. CODE Ann. § 16-13-24 (West 2009) (establishing five schedules of controlled substances); see id. § 16-13-25 (West 2009 \& Supp. 2013) (listing Schedule I controlled substances); see id. § 16-13-26 (listing Schedule II controlled substances and explicitly referring to opiates) (West 2009 \& Supp. 2013); see also id. § 15-6-61 (listing superior court clerk’s duties).

377. See generally Superior Court, ATHENS-ClARKE CTY., https://www.athensclarkecounty .com/579/Superior-Court [https://perma.cc/J3N3-JSKT] (last visited Apr. 14, 2019); Clerk of Superior \& State Courts, ATHENS-CLARKE CTY., https://www.athensclarkecounty.com/324/Clerk-of-SuperiorState-Courts [https://perma.cc/C2VL-C9MW] (last visited Apr. 14, 2019).

378. Telephone Interview with Betty Logan, Clerk of Courts, Athens-Clarke County (July 25, 2018).

379. Id. 
of the budget then is multiplied by the opioid effort of ten percent for an opioid-related service cost of $\$ 20,000$. In sum, in our hypothetical example, opioid-related services amount to four percent of the total court administration costs.

Fig. 1: Hypothetical Calculation of Court Costs

Total department budget: $\$ 500,000$

Percentage of criminal cases involving opioids: 10\% (based on docket, criminal codes)

Percentage of total costs related to criminal cases: $40 \%$ ( 2 out of 5 staff)

$(500,000)(40 \%)=\$ 200,000$

$(200,000)(10 \%)=\$ 20,000$ (opioid cases represent $4 \%$ of total budget)

Sadly, opioid-related services in a local coroner's office also are easy to track. Georgia Law requires all suspected overdose cases in Georgia to be sent to the Georgia Bureau of Investigation (GBI) for a toxicology screening, which will show whether opioids were in the decedent's system at the time of death. ${ }^{380}$ Costs related to an opioid overdose include the GBI toxicology report, cost to transport the body, and local coroner's office staff time in locating a person who will claim the body. ${ }^{381}$ Additional costs may be incurred when no one will claim the body and the county must get approval from the Superior Court for a pauper burial, or if the county must embalm and retain the body for a period of time before

380. Rhonda Cook, At the State's Morgue, a Backlog Has Grown Amid Opioid Epidemic, ATLANTA J.-CONST. (Sept. 14, 2017), https://www.ajc.com/news/local/the-state-morgue-backloghas-grown-amid-opioid-epidemic/9gtLuiR2ND6wcgcuGGpffN/ [https://perma.cc/WC2V-LRZQ]; Medical Examiner's Office, GA. BUREAU OF INVESTIGATION, https://gbi.georgia.gov/medicalexaminers-office [https://perma.cc/AEW9-JNP2] (last visited Apr. 22, 2019); GA. CODE ANN. § 4516-24 (West 2003 \& Supp. 2015) (describing when notification to the coroner or county medical examiner is required upon discovery of a death under listed circumstances); see id. § 45-16-25 (West 2003 \& Supp. 2013) (describing coroners' duties upon receipt of notice described in $\S 45-16-24$ ); see id. § 45-16-27 (describing when coroners shall require an inquest); see id. § 45-16-27.1 (West 2003) (describing when autopsies are required).

381. See Frequently Asked Questions About Autopsies, Ga. Bureau of Investigation, https:/gbi.georgia.gov/sites/gbi.georgia.gov/files/related_files/site_page/88332299Autopsy\%20FAQ s.pdf [https://perma.cc/6XZM-68DD] (last visited Apr., 14, 2019) (detailing when an autopsy is required under state law, how autopsies are paid for, the coroner's obligation to transport the body to and from morgue, and indicating how long an autopsy typically takes to complete). 
investigation. ${ }^{382}$ So, again, there is a reason extrinsic to local government function to collect the opioid-specific data related to coroners' costs.

Another easily identifiable cost, applicable to various local government departments, is the cost of naloxone, including the cost of acquiring and storing the drug as well as training employees on its use. Naloxone may be stocked by police, fire, EMS, as well as libraries and schools (although schools are not local government costs, as explained above). ${ }^{383}$ Our interviews, as well as media sources, ${ }^{384}$ revealed an increasing number of local government departments that are stocking naloxone and training their staff to use it. ${ }^{385}$ For services where opioidrelated issues will be minimal, such as drug use in a public library, costs should be limited to purchasing naloxone and training staff on how to use it. These costs would be fairly easy to isolate: the cost of the drug and the hourly cost of employees for the time spent in training. Any department that purchases naloxone (e.g., police, fire/EMS) can track this direct cost through its financial system. Furthermore, the specific training guidelines for administering the drug ensure an easy calculation of employee time and cost for knowing how to use it.

One caveat is that naloxone-related costs may be both over- and underinclusive with respect to actual opioid overdoses, as explained by Hall

382. Div. of Aging Servs., Ga. Dep't of Hum. Servy., A Guide to Funeral Homes, CREMATORIES AND CEMETERIES 8-9 (2011), http://medicalboard.georgia.gov/sites/aging. georgia.gov/files/imported/DHR-DAS/DHR-DAS_Publications/A\%20Guide\%20to\%20Funeral\%20 Homes-2011\%20FINAL\%204-29.pdf [https://perma.cc/P8NU-MJNU] (explaining that the county may cover burial expenses if the decedent is a "pauper and destitute of the means of paying for decent interment.").

383. See supra Section IV.A.

384. J. Brian Charles, Beyond Books: How Libraries Are the Latest Front in the Opioid Fight, GOVERNING (June 12, 2018), http://www.governing.com/topics/health-human-services/gov-librariesopioid-epidemic-lc.html; Corey S. Davis, et al., Expanded Access to Naloxone Among Firefighters, Police Officers, and Emergency Medical Technicians in Massachusetts, 104 AM. J. OF PUB. HEALTH e7, e8 (Aug. 2014), https://www.ncbi.nlm.nih.gov/pmc/articles/PMC4103249/pdf/AJPH. 2014.302062.pdf [https://perma.cc/5MFR-6LHM]; Soumya Karlamangla, Police Use of Naloxone Saved a Dozen Who Overdosed in Chico, Calif., Valley News (Jan. 20, 2019), https://www.vnews.com/The-drug-that-saved-the-people-who-overdosed-in-Chico-22908941 [https://perma.cc/37Q9-SP8Q].

385. Hall County Library, Hall County Fire Services/EMS, Grady EMS (serving Decatur County), and Athens-Clarke County Police Department reported stocking naloxone and training staff to use it. Telephone interview with Lisa MacKinney, Director, Hall County Library (Aug. 13, 2018); Telephone Interview with Randy Williams, Director of Operations, Randolph County - Grady EMS (Aug. 1, 2018); Telephone Interview with Garry Epps, Lieutenant, Drug Task Force, Christopher Nichols, Lieutenant, Office of Professional Standards and Recruitment, Benjamin Dickerson, Lieutenant, Career Development \& Training Unit, Athens-Clarke County Police Department (Aug. 9, 2018); Telephone Interview with Scott Bowden, Christie Grice, Division Chief, Emergency Medical Services, and Jerry Smith, Assistant Chief, Hall County Fire Services/EMS (Aug. 24, 2018). 
County EMS. ${ }^{386}$ That is because their protocol, adopted based on national standards, calls for naloxone administration only if the patient is unconscious and has a blocked airway. ${ }^{387}$ Thus, there may be cases where a patient actually was in cardiac arrest, unrelated to drug overdose, but nevertheless receives naloxone. Likewise, there may be patients who have overdosed, including on opioids, but do not receive naloxone because they are still conscious. One reason for the relatively conservative protocol is that the immediate withdrawal effect of naloxone can cause agitation and aggression; thus, avoiding administration on conscious patients may be safer for the patient and emergency responders. ${ }^{388}$ The Hall County EMS personnel interviewed suggested that other departments, such as police, are more liberal in their naloxone use. ${ }^{389}$ Even if naloxone administration exceeds actual opioid-related overdoses, it still could be fairly argued that the costs are a result of the opioid epidemic.

For two of the services we researched, the benefit-received model for providing government services does apply: emergency medical services (EMS) and hospital care. These services already bill patients via health insurance (private or public) and track uncompensated care, and, consequentially, have systems in place for tracking costs related to particular patient diagnoses or interventions, namely, the ICD-10 codes described above in other cost studies. To track opioid-related costs, EMS providers and hospitals simply would need to access existing billing and coding records in their data management systems. That said, the specificity and accuracy of data entries could pose a limit on the ease of collecting these data. EMS, for example, may not specify more than "suspected overdose," without indicating the drug type or types. ${ }^{390}$ Although a toxicology screen may be performed at the hospital when the patient arrives, there is no reason intrinsic to the provision of emergency medical treatment and transport services to report those results back to the EMS unit. EMS is indeed a cost borne by local governments, even if the

386. Telephone Interview with Scott Bowden, Christie Grice, Division Chief, Emergency Medical Services, and Jerry Smith, Assistant Chief, Hall County Fire Services/EMS (Aug. 24, 2018).

387. Id.

388. Id.; Daniel P. Wermeling, Review of Naloxone Safety for Opioid Overdose: Practical Considerations for New Technology and Expanded Public Access, 6 THERAPEUTIC ADVANCES IN DRUG SAFETY 20, 21 (2015), https://www.ncbi.nlm.nih.gov/pmc/articles/PMC4308412/ pdf/10.1177_2042098614564776.pdf [https://perma.cc/6C8Q-F53G] (internal citation omitted) (noting that patients "undergoing acute opioid withdrawal . . will be agitated as they are being revived with naloxone, thus increasing the risk of an injury to the provider.").

389. Telephone Interview with Scott Bowden, Christie Grice, Division Chief, Emergency Medical Services, and Jerry Smith, Assistant Chief, Hall County Fire Services/EMS (Aug. 24, 2018).

390. Telephone Interview with Randy Williams, Director of Operations, Decatur-Grady 911 (Aug. 1, 2018). 
subsequent hospital emergency department or acute care services are not.

Even with the possible service-specific coding data, the bulk of opioid-related EMS and hospital services will be funded through sources other than city and county governments. Patients may have private insurance (through employers or other individual and small-group market plans) or government health insurance (through Medicare, Medicaid, or federal or state employee health plans) that covers most of the cost of services provided. ${ }^{391}$ To the extent those payors undercompensate, hospitals already have systems in place for addressing the shortfall, which rarely has financial implications for local governments. ${ }^{392}$ Even in the case of opioid-affected infants specifically identified in the local government plaintiffs' complaints, they would almost certainly qualify for Medicaid coverage, a program that is jointly funded by states and the federal government, but not cities and counties. ${ }^{393}$

We discuss jail costs more fully below under the "medium" category, but any hospital costs (as opposed to on-site jail infirmary) for inmates typically are billed directly to the county, we learned. ${ }^{394}$ Even if the inmate is Medicaid or Medicare eligible, those third-party payors are not billed (a point of some controversy between jail and county administration, it seems). ${ }^{395}$ Thus, if an inmate receives emergency medical treatment, hospital-based detox, or other drug treatment services at the hospital instead of at the jail, those costs would likely be easy to identify through CPT codes as above. Those costs are discrete but likely fairly modest for any given county.

It is possible that patients utilizing EMS or hospital services are city or county employees, in which case those and any other associated treatment (e.g., outpatient treatment, counseling and therapy, recovery assistance) would be a cost to the local government if the employee is covered by an employee health plan or workers compensation. For this reason, we included heads of Human Resources departments for the three counties in our interviews. ${ }^{396}$ For government employees, some opioid-

\footnotetext{
391. Id.

392. Telephone Interview with Jim Lambert, CEO, Memorial Hospital and Manor, Hospital Authority, Decatur County (July 26, 2018).

393. Financial Management, MEDICAID.GOv, https://www.medicaid.gov/medicaid/finance/ [https://perma.cc/H4AC-8MAL] (last visited Apr. 22, 2019).

394. Telephone Interview with Garry Epps, Lieutenant, Drug Task Force, Christopher Nichols, Lieutenant, Office of Professional Standards and Recruitment, Benjamin Dickerson, Lieutenant, Career Development \& Training Unit, Athens-Clarke County Police Department (Aug. 9, 2018); Telephone Interview with Tommy York, Jail Commander, Athens-Clarke County (Aug. 10, 2018). 395. Id.

396. Telephone Interview with Michelle West, Accounting Manager, Human Resources for
} 
related costs are easily calculated while others would be more difficult to capture. City and county Human Resources departments can gather employee medical costs related to opioid-related drug treatment, drug overdose, and other mental health and substance abuse benefits, assuming that medical billing records are coded by drug type. ${ }^{397}$ Local governments may self-insure or purchase their employee health plans and workers' compensation coverage, but the service-benefit recordkeeping would be the same.

For example, ICD-10-CM codes from category T40 (overdose) denote the specific substance relating to the overdose, the intent of the overdose (accidental, intentional self-harm, assault, and undetermined), and the type of encounter (i.e., initial, subsequent, or sequela). ${ }^{398}$ Category F11 denotes use, abuse, or dependence, and captures associated complications including, for example, delirium, mood disorder, sleep disorder, withdrawal. ${ }^{399}$ Other related conditions commonly associated with opioids include acute respiratory failure ${ }^{400}$, acute kidney failure ${ }^{401}$, coma $^{402}$, liver failure, and constipation. ${ }^{403}$ Local governments also know how much they pay for employees' opioid medications covered by the employee health plan. ${ }^{404}$ They also could track when certain employees are unable to work because of an opioid prescription, e.g., a sanitation worker who cannot drive a garbage truck because he is taking opioids following minor surgery. The costs associated with that lost productivity

Decatur County (July 23, 2018); Telephone Interview with Traci Mason, Benefits and Wellness Administrator for Athens-Clarke County (Aug. 7, 2018).

397. Id.

398. Poisoning by, Adverse Effect of and Underdosing of Narcotics and Psychodysleptics (Hallucinogens), AAPC CODER, https://coder.aapc.com/icd-10-codes/T40 [https://perma.cc/8FPVE6GC] (last visited Apr. 22, 2019).

399. ICD-10 Code for Opioid Related Disorders F11, AAPC CODER, https://coder.aapc.com/icd10-codes/F11 [https://perma.cc/VB75-ZGZB] (last visited Apr. 22, 2019).

400. Rajnish K. Gupta, MD \& David A. Edwards, MD, PhD, Monitoring for Opioid-Induced Respiratory Depression 32 J. Anesthesia Patient SAFETy Found. NewsL. 70,70 (Feb. 2018), https://www.apsf.org/article/monitoring-for-opioid-induced-respiratory-depression/ [https://perma. cc/H9JM-JSTG].

401. Mary Mallappallil et. al, What Do We Know About Opioids and the Kidney?, 18(1) INT. J. Mol. SCI. 1, 4 (Jan. 2017), https://www.ncbi.nlm.nih.gov/pmc/articles/PMC5297852/ [https://perma.cc/PQW5-P5V8].

402. Will Dane et. al, The Solution to Opioids is Treatment, BraIN InJ. Ass'N OF AM., https://www.biausa.org/public-affairs/media/the-solution-to-opioids-is-treatment [https://perma.cc/ JQK4-PV2A] (last visited Apr. 22, 2019).

403. Opioid Use Disorder, AM. PSYCHIATRIC AsS'N (Nov. 2018), https://www.psychiatry.org/ patients-families/addiction/opioid-use-disorder/opioid-use-disorder [https://perma.cc/2875-DRJA] (last visited Apr. 22, 2019).

404. Telephone Interview with Michelle West, Accounting Manager, Human Resources for Decatur County (July 23, 2018); Telephone Interview with Traci Mason, Benefits and Wellness Administrator for Athens-Clarke County (Aug. 7, 2018). 
would appear as sick leave.

In some instances, local government provide grants or subsidies to the safety net hospitals that serve their communities. Our interviews suggested that county indigent care grants are the exception, not the norm. In Georgia, it is entirely within the discretion of counties whether to provide indigent care funds to their safety net hospitals. ${ }^{405}$ Atlanta's Grady Health Systems receives funds from Fulton and Dekalb counties in metro Atlanta. Northeast Georgia Health System, which has the second busiest emergency room in the state, ${ }^{406}$ after Grady, is the safety net provider for Hall county. It receives no local government funding from any of the counties that it serves. Even when grants are extended, the city or county does not directly cover the costs of medical service but only subsidizes them; thus, determining the government's opioid-related costs requires additional steps. For example, suppose a government subsidizes its local hospital for indigent care by giving the hospital $\$ 500,000$ annually. The hospital first would need to sum all the costs related to indigent care, and then isolate those indigent care patients that had opioidrelated costs. The percentage of opioid-related indigent care costs would be multiplied to the subsidy of $\$ 500,000$ to determine the county's opioidrelated damages. A hypothetical calculation is below.

Fig. 2: Hypothetical Calculation of Hospital Indigent Care Costs

County indigent care grant: $\$ 500,000$

Total hospital indigent care costs: $\$ 1.5$ million

Indigent care costs related to opioids: $\$ 30,000$

Percentage of indigent care costs related to opioids: $2 \%$

$(\$ 500,000)(2 \%)=\$ 10,000$ (county costs for indigent opioid care)

Finally, any opioid-related grants or spending specifically allocated to local drug treatment centers grants or other facilities should also be easy

405. See David Wickert, Fulton could cut spending on Grady by $\$ 25$ million, ACJ (Nov. 19, 2013), https://www.ajc.com/news/fulton-could-cut-spending-grady-million/b6sxS2q5YioFW9Pg6X $\mathrm{m} 5 \mathrm{aN} /[\mathrm{https}: / /$ perma.cc/L8NM-FEE2].

406. Courtney O'Neal-Hill, Top of the List: Atlanta's Largest Hospitals and Georgia's Top HMOs, Atlanta Business Chronicle (Oct. 28, 2016, 6:00 AM), https://www.bizjournals.com/ atlanta/news/2016/10/28/top-of-the-list-atlantas-largest-hospitals-and.html. 
to track. For example, the Hall County Treatment Center has grants specifically for MAT, the amounts of which could be readily identified as opioid-related spending. ${ }^{407}$ Other Community Development Block Grants $(\mathrm{CBDG})^{408}$ would be easy to quantify, if dedicated to opioids. If geared toward drug treatment more generally, however, additional research would have to be conducted to identify the portion of the grantee's work was in the service of those with opioid use disorders and addiction. To capture these types of costs, we included local government finance department representatives in our interviews because any city or county grants would be managed there. ${ }^{409}$

In sum, our qualitative interview results suggest that the "easy" category is smaller than we anticipated, presenting clear challenges for plaintiffs and their attorneys in demonstrating damages in the lawsuits, as well as for local governments deciding on resources to allocate to the opioid epidemic. With respect to the litigation, there seems to be very little cost or other downsides for cities and counties to join the MDL. Plaintiffs' attorneys front the costs, present ready-to-file complaints, and offer the promise of "free" money to budget-strapped local governments. But as the discovery and settlement process unfolds in Judge Polster's MDL and other courts, local governments may be struggling to respond to discovery and other requests. Indeed, a group of cities suing in Connecticut recently were dismissed on standing grounds for failing to demonstrate cognizable injury. ${ }^{410}$ Predictably, other local government plaintiffs will meet similar challenges, on standing or other grounds, as these cases proceed.

\section{Medium to Quantify}

The "medium" category includes costs that take more effort to quantify and those for which the ease of determining specific amounts may

407. Telephone Interview with Nancy Smallwood, Grants Manager, Joy Walker, Housing Information Specialist, and Zachary T. Propes, Financial Services Director, Hall County Financial Services (Aug. 24, 2018).

408. Community Development Block Grants (CDBG), GA. DeP'T OF CMTY. AFF., https://www.dca.ga.gov/community-economic-development/funding-programs/communitydevelopment-block-grants-cdbg [https://perma.cc/BE3U-L9TS] (last visited Apr. 14, 2019).

409. Telephone Interview with Nancy Smallwood, Grants Manager, Joy Walker, Housing Information Specialist, and Zachary T. Propes, Financial Services Director, Hall County Financial Services (Aug. 24, 2018).

410. See Cities Appeal Dismissal of Lawsuits Against Opioid Makers, Associated PrESS (Jan. 23, 2019), https://www.apnews.com/aae6b967e1a547e9b3f2dcccc534de42 [https://perma.cc/QLQ7G4Y2] ("Judge Thomas Moukawsher in Hartford ruled Jan. 8 the lawsuits are not allowed because they were not filed as government enforcement actions authorized by state public interest laws.... [concluding] opioid manufacturers cannot be held responsible to municipalities for indirect harms from the opioid crisis."); see also Schott, supra note 370. 
vary depending on a jurisdiction's particular recordkeeping practices. Our "medium" category includes jails, county attorneys (prosecutors and public defenders) and courts, parks and recreation, and police (both drug enforcement and code enforcement authorities). Some of the additional effort would be retrospective, culling through records to identify historical costs not otherwise captured. Some would be prospective, putting in place tracking software or other systems, or creating feedback loops, such as the suggestion above for hospital toxicology screens to be reported back to EMS. One of our follow-on projects for this qualitative research is to develop those sorts of systems and train local governments on their use, work that is very much in keeping with the service and outreach mission of the University of Georgia, and similarly situated land-grant universities. $^{411}$

One example of "medium" costs that could be tracked with some additional steps include jail costs. ${ }^{412}$ The ability to track opioid-related effort will be "easy" or "medium" depending on whether the sheriff tracks why a person is incarcerated in a way that allows a retrospective search of the data. Jails may or may not record the criminal code corresponding to the arrest or otherwise update intake data following plea or conviction. Even if data more specific than "DUI" or "possession" is recorded, it may not be in an easily searchable database, requiring a time-intensive review of records. City and county jail populations include a mix of pre-trial detainees (the majority) and convicted inmates (serving sentences for misdemeanors and sometimes serving shorter felony sentences not transferred to a state facility).

If the jail does record reasons for incarceration, then a similar calculation to the courts' costs example above could be done. ${ }^{413}$ The average per-inmate cost (i.e., roughly $\$ 45 /$ day/per inmate in AthensClarke County $)^{414}$ could be multiplied by the number of opioid-related incarcerations. Absent those data, jails at least could determine prisoner

411. The Mission of the University of Georgia, UNIV. OF GA., https://www.uga.edu/mission.php [https://perma.cc/TM4Q-NESZ] (last visited Apr. 22, 2019).

412. See generally About GDC, GA. DEP'T OF CORR., http://www.dcor.state.ga.us/ AboutGDC/About [https://perma.cc/BH73-ZBSH] (last visited Apr. 22, 2019); see also CHRISTIAN

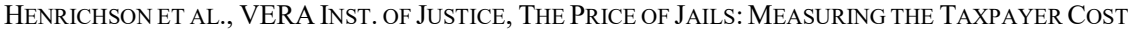
OF LOCAL INCARCERATION 4 (May 2015), https://storage.googleapis.com/vera-web-assets/ downloads/Publications/the-price-of-jails-measuring-the-taxpayer-cost-of-local-incarceration/ legacy_downloads/price-of-jails.pdf [https://perma.cc/A2RM-6S5A].

413. See supra Figure 1.

414. Telephone Interview with Tommy York, Athens-Clarke County Jail Commander (Aug. 10, 2018). 
medical costs related to opioids, including detoxification, MAT, ${ }^{415}$ and any other associated medical and mental health costs. Prisoners needing those services are already identified and the drug and medical costs are easily traceable. If the detox occurs on-site, medical staff time can be calculated based on number of days in the infirmary. If the detox occurs at the local hospital, according to our interviews, the county pays directly, on a cost basis, for any services provided to prisoners, as described above under the "easy" category. ${ }^{416}$

Court administration, as discussed above, seems fairly easy to track as those administrative costs are directly borne by local governments. The question becomes harder for other legal departments, including public defenders; ${ }^{417}$ prosecutors (which may include district attorneys, who handle felonies, or solicitors general, who handle misdemeanors in some larger counties); ${ }^{418}$ Superior Courts, ${ }^{419}$ which include Accountability Courts $^{420}$ and, as subsets, Drug Courts and Mental Health Courts; ${ }^{421}$ Juvenile Courts, ${ }^{422}$ other limited-jurisdiction courts, such as State Courts in some counties ${ }^{423}$ which hear misdemeanors, including DUI, and may also have separate Drug/DUI tracks; ${ }^{424}$ and Municipal Courts, ${ }^{425}$ which may hear code violations, shoplifting, marijuana possession, and other low-level cases. Additionally, some counties may use Probate and Magistrate Courts for certain misdemeanors, other minor crimes, and preliminary matters and proceedings. ${ }^{426}$ The county Clerk of Courts may

415. See generally Jailed-Based MAT: Promising Practices, Guidelines and Resources, NAT'L COMM'N ON CORR. HEALTH CARE (Nov. 7, 2018), https://www.ncchc.org/jail-based-MAT [https://perma.cc/L3QV-ZNZP].

416. Telephone Interview with Tommy York, Athens-Clarke County Jail Commander (Aug. 10, 2018).

417. GA. CODE ANN. § 17-12-23 (West 2014).

418. Prosecuting Attorneys' Council of Georgia, GA. Gov, https://georgia.gov/ agencies/prosecuting-attorneys-council-georgia [https://perma.cc/6STT-RGCK] (last visited Apr. 22, 2019). See also Telephone Interview with C.R. Chisholm, Athens-Clarke County Solicitor (July 31, 2018).

419. See generally GA. SUPER. CTS., https://georgiasuperiorcourts.org [https://perma.cc/6BG7NNU8] (last visited Apr. 14, 2019).

420. See generally GA. ACCOUNTABILITY CTS., https://www.gaaccountabilitycourts.org [https://perma.cc/RQ9A-S8PR] (last visited Apr. 14, 2019) and COUNCIL OF JUV. CT. JUDGES OF GA., http://cjcj.georgiacourts.gov [https://perma.cc/LWY4-XW4N] (last visited Apr. 14, 2019).

421. GA. CODE ANN. § 15-1-15 (West 2009 \& Supp. 2013).

422. Id. § 15-11-50 (West 2009); Id. § 15-11-28 (West 2009 \& Supp. 2013).

423. Id. § 15-7-4 (West 2009 \& Supp. 2013).

424. State Court, ATHENS-ClarKe CTY., https://www.athensclarkecounty.com/954/State-Court [https://perma.cc/Y4AS-NAGH] (last visited Apr. 14, 2019).

425. GA. Code ANN. § 36-32-1 (West 2003 \& Supp. 2013).

426. Georgia's Court Structure, Jud. Council of Ga. Admin. Office of the CTS., http://municipal.georgiacourts.gov/content/georgia\%E2\%80\%99s-court-structure [https://perma.cc/ 
oversee both the Superior Court and limited-jurisdiction courts. ${ }^{427}$

For these various legal departments, opioid-related costs are hard to track and attribute to local governments for various reasons. First, the funding is a mix of state and city or county dollars. Funding for Superior and Juvenile Courts in Georgia is a mix of state and county sources, while the courts of limited jurisdictions are city or county-funded. ${ }^{428}$ Public defenders' and district attorneys' salaries primarily come from the state, although counties may supplement them. ${ }^{429}$ That said, the state public defender system funds only one Superior Court public defender per county and only a portion of Juvenile Court public defenders and defenders' support staff. Caseloads typically require additional public defenders, which are county-funded. For counties with Solicitors General, the county pays their compensation. ${ }^{430}$ Thus, the first task would be identifying which cases were handled by which courts and attorneys, recognizing that cases may move among various venues and personnel as charges are added, dropped, or settled. That disaggregation task alone would be daunting.

Second, even assuming some cases could be identified as countyfunded, those employees typically do not track costs related to particular charges in the same manner as Court Administration, described above. Thus, local governments would need to implement new systems to track staff time for opioid-related cases. Historically, local government legal departments have not needed to "bill" their time (in contrast to some private attorneys). Accordingly, any attempt to capture data on opioidrelated cases specifically would require a cultural change. These departments might retroactively compile those data by combing through old case files, which may or may not be electronic or term-searchable. The Government Plaintiff Fact Sheet described above calls for ten years of historical data on court expenditures with respect to each category of damages. ${ }^{431}$ To create any historical dataset would require not only timeconsuming, tedious work but also assumptions about the amount of time spent on cases, or creating average time estimates for types of cases (e.g., pleas versus trials, single versus multiple defendants, single versus multiple charges, type of charge).

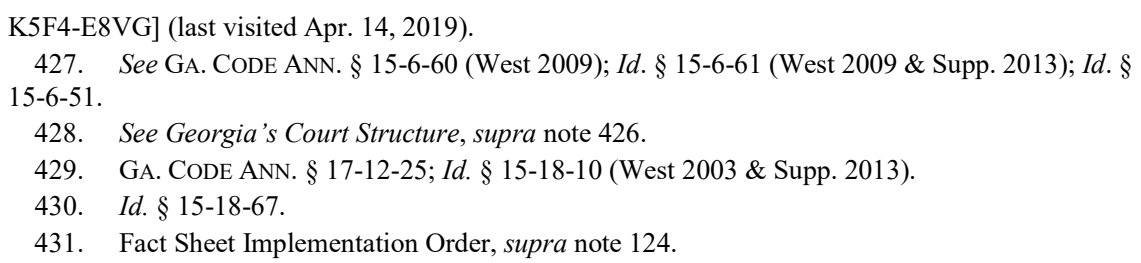


If a tracking system were implemented, then the total time in a fiscal year dedicated to cases involving opioids would be divided by the total time spent on all cases to create an opioid effort, similar to the Court Administration calculation above. ${ }^{432}$ All that being said, a number of cases still might not be captured. For example, the charged offense may not be drug-related, such as a non-violent theft offense, even though the offender suffers from an addiction and may enter treatment programs through the Drug Court. In sum, the calculation of local government judicial system costs related to opioids, aside from Court Administration, would be challenging.

Opioid-related costs for Parks and Recreation (sometimes called Leisure Services) departments might include cleaning up drug paraphernalia from homeless camps or other locations that opioid-users frequent. The costs would include the city or county workers' time and any special equipment and training to safely collect and dispose of the waste. If police accompaniment is needed for safety of the workers, those costs would also be included. For the three counties we interviewed, this had not become a significant issue, but reports from other parts of the country reveal that the problem does exist and may even be prevalent enough to warrant providing needle disposal containers in public places. ${ }^{433}$ We include the costs in our "medium" category, for now, because the problem is not yet prevalent at least in the three localities we interviewed. Another potential cost for local government recreational facilities are public campgrounds, such as in Hall County. ${ }^{434}$ Enforcement issues might include drug paraphernalia clean-up, as above, and other rules enforcement, such as noise or other disturbances, overstaying time-limits, and evictions. ${ }^{435}$

In a few discrete instances, law enforcement efforts related to opioids could be captured if additional tracking systems were implemented. In Georgia, police are city departments and sheriffs are county departments. The local government funding source is clear, although state and federal enhancement is possible. ${ }^{436}$ In some cases, local law enforcement officers

\section{Supra Figure 1.}

433. Kevin Miller, Portland Adds Needle Disposal Boxes in Some City Parks as Heroin Crisis Continues, PRESS HERALD (Sept. 22, 2015), https://www.pressherald.com/2015/09/22/portland-addsneedle-disposal-boxes-in-some-city-parks-as-heroin-crisis-continues/ [https://perma.cc/WS2LFXPW].

434. Telephone Interview with Mike Little, Hall County Parks \& Leisure (Aug. 7, 2018).

435. Id.

436. There have been proposals to enhance police but not necessarily sheriffs and their deputies' salaries with state dollars. Greg Bluestein, Panel Eyes \$7 Million in State Funds to Boost Local Cop Pay in Georgia, ATLANTA J.-CONST. (Dec. 20, 2017), https://www.ajc.com/news/state-regional- 
may participate in drug enforcement efforts such as multi-county drug task forces. ${ }^{437}$ Their work is typically planned and targeted to arrest drug dealers and manufacturers, such as methamphetamine labs. ${ }^{438}$ Whether opioids are involved in an investigation may not be known until an arrest is made and the drugs are collected. For example, the officers may build a case of known cocaine dealer only to also seize heroin when an arrest is made. But, again, law enforcement investigators do not track the hours spent on each case. Therefore, even with investigations and arrests known to be drug-related, law enforcement agencies would need to develop a system to track time spent on each case, as well as additional costs like travel. Still, they would need to segregate resources spent on investigations involving opioids, which, in some cases, may require retrospective data culling and analysis, similar to the approach for identifying legal departments' efforts and overhead related to opioids, assuming the local government costs could be isolated.

Aside from those particular scenarios, law enforcement costs related to opioids will be challenging to track because those services, along with fire, emergency response, sanitation, public works, and other departments, are provided as public goods, not on a benefit-received model. Public goods are those in which one cannot isolate the benefits of a good, resulting in the classic "free rider problem" and undersupply of these goods in the private sector. ${ }^{439}$ The classic example is fire protection which benefits not just the person whose house is on fire but also neighbors' homes when the fire is extinguished. Likewise, it is often impractical to isolate beneficiaries of a service and make them pay for it. Can you imagine having a toll road on every street corner? In essence, local governments and the public do not expect local governments to charge for services based on a specific cost or benefit received for their core services: police, fire, street maintenance. Rather, the public's expectation is that the

govt-politics/panel-eyes-million-state-funds-boost-local-cop-pay-georgia/F8pB3alhhKbib6BTkx4 C5K/ [https://perma.cc/2KQV-SG6K]; Craig Schneider, Sheriff's Deputies: We Face Highest Risk But Lowest Pay, ATLANTA J.-CONST. (Sept. 16, 2016), https://www.ajc.com/news/local/sheriff-deputiesface-highest-risk-but-lowest-pay/9qCwAO7PcOMF61F7QyykFO/ [https://perma.cc/XA8Z-AW3L]. Also, some local police departments may receive grants, including federal funds. See Hilary Bitschek, Ga. SWAT Team Gets Over $\$ 700 K$ in Funding, MARIETTA DAILY J. (Feb. 20, 2015), https://www.policegrantshelp.com/news/8311290-ga-swat-team-gets-over-700k-in-funding/ [https://perma.cc/QPQ7-MB44].

437. See, e.g., Regional Drug Enforcement Offices, Ga. Bureau of Investigation, https://investigative-gbi.georgia.gov/regional-drug-enforcement-offices [https://perma.cc/T74QFXAR] (last visited Apr. 14, 2019).

438. Telephone Interview with Gary Epps, Christopher Nichols, \& Benjamin Dickerson, AthensClarke County Police Department (Aug. 9, 2018).

439. See generally Richard A. Musgrave \& Peggy B. Musgrave, Public Finance in Theory and Practice 7-8 (1984); Gerald E. Frug, City Services, 73 N.Y.U. L. Rev. 23, 25-35 (1998) (surveying dominant theories and literature on city services as public goods). 
city or county will provide those services at a level supported by the majority of the community. Moreover, some users of a service - such as a jail or court system - are not the beneficiaries. Rather, the public is by having a safer community. In sum, local governments at their core exist to provide services where costs and benefits cannot be traced to individuals and, thus, have not developed specific user and cost tracking systems. Although such systems might be designed to better capture opioid-related costs, the implementation itself would require expertise and resources, personnel, financial, and other.

\section{Hard to Quantify}

The third category of costs, those that are very hard to quantify, was larger than we expected. This category includes not only indirect and intangible costs but also seemingly straight-forward, identifiable costs, including emergency communications (i.e., 911 calls), criminal investigations, code enforcements, and city and county personnel costs. We discuss the surprisingly hard direct costs first then briefly identify a host of indirect and intangible costs.

911 is a county-level service in Georgia, although some funding may come from the state, including a sales tax on prepaid phones. ${ }^{440}$ Calls may be coded as suspected overdose but not necessarily opioid-related. Unlike law enforcement through a drug task force where investigative work is planned and focused on narcotics, patrol work is reactionary. Officers ${ }^{441}$ respond to 911 calls and initiate incidents based on observations, such as pulling over a driver who is weaving across road lanes. After responding to a call for service, officers write a narrative, regardless of whether an incident report was made. ${ }^{442}$ While these incidents could potentially provide data on whether opioids were involved, most law enforcement departments use a form of electronic report-writing to speed the process for the officers. ${ }^{443}$ These data systems have general categories of crimes,

440. See Mark Niesse, Georgia 911 Agencies Mysteriously Lose \$5 Million in State Funding, ATLANTA J.-CONST. (Dec. 19, 2017), https://www.ajc.com/news/state-regional-govtpolitics/georgia-911-agencies-mysteriously-lose-million-state-funding/Mb3NEkFyamAYJ0GuRq3 $\mathrm{PzJ} /[\mathrm{https}: / /$ perma.cc/Y3TB-C8TS] (reporting that $\$ 5$ million in state funding for 911 from $\$ .75$ tax on prepaid phones had seemingly disappeared).

441. This explanation applies to police officers and sheriff deputies. For this report, we use just the term "officers" for consistency.

442. Telephone Interview with Gary Epps, Christopher Nichols, \& Benjamin Dickerson, AthensClarke County Police Department (Aug. 9, 2018).

443. Cindy Coleman, How Incident Reporting Impacts Officer Productivity and Safety, POLICEONE.COM (Aug. 6, 2018), https://www.policeone.com/police-products/police-technology/ software/report-writing/articles/478769006-How-incident-reporting-impacts-officer-productivity- 
such as assault, robbery, and narcotics, that an officer checks to easily classify the reason for the stop or arrest. Where narcotics are a factor in a service call, an officer may include the types of drug or drugs found in the report narrative but relatively few departments would have an easy way to quickly search every report to determine if opioids were included. ${ }^{444}$ Other 911 calls may not even indicate suspected overdose, but simply that a person is unresponsive or unconscious. Also, some 911 centers serve multiple jurisdictions, requiring a tracking system to identify calls for particular cities or counties.

For 911 calls involving police and crime, as stated earlier, arrests involving opioids can be tracked through docket databases of the Clerk of Court. ${ }^{45}$ But applying only those cases to a calculation of law enforcement effort with narcotics (a broader category, a subset of which would be opioids) would understate the actual impact on the department because many officer calls do not result in specific arrests for opioids. Under Georgia's safe harbor statute, a person calling 911 for assistance with an overdose will not face criminal charges nor will the person who has overdosed. ${ }^{446}$ Therefore, an officer can assist with an overdose call, including but not limited to administering naloxone, and neither the person calling nor the person receiving treatment will be arrested. ${ }^{447}$ In some cases, including a video that went viral on social media, the person calling may even be the addict's dealer. ${ }^{448}$

As discussed under the review of earlier opioid studies, opioids are undoubtedly a driving force for property crime as addicts commit those crimes to pay for their drugs. Because clearance rates for property crimes are generally low (e.g., nationally, $19.2 \%$ in 2017 for larceny-theft) ${ }^{449}$ law enforcement at a local level often cannot say what percentage of property crime was specifically associated with narcotics, much less opioids

and-safety/ [https://perma.cc/Q3JT-A6BW] (noting that over two-thirds of departments surveyed use electronic police reporting software).

444. See, e.g., Telephone Interview with Gary Epps, Christopher Nichols, \& Benjamin Dickerson, Athens-Clarke County Police Department (Aug. 9, 2018).

445. Telephone Interview with Betty Logan, Athens-Clarke County Clerk of Courts (July 25, 2018).

446. GA. CODE ANN. § 16-13-5(b) (2014).

447. Id.

448. Katharine Q. Seelye, et al., How Do You Recover After Millions Have Watched You Overdose?, N.Y. TIMES (Dec. 11, 2018), https://www.nytimes.com/2018/12/11/us/overdosesyoutube-opioids-drugs.html [https://perma.cc/M2H2-SGQC] (discussing viral videos of overdoses across the United States).

449. 2017 Crime in the United States, Fed. Bureau of InVestigation, https://ucr.fbi.gov/ crime-in-the-u.s/2017/crime-in-the-u.s.-2017/topic-pages/clearance-browse-by/national-data [https://perma.cc/9PLY-4KX5] (last visited Apr. 22, 2019). 
specifically. Similarly, housing code and other city- or county-ordinance violations are hard to correlate with opioids as opposed to drugs more generally or a host of other socioeconomic, medical, and other factors. As one code enforcement officer explained, their officers may be called out to a property or identify a property because of piles of garbage in the yard, noise, or other disturbances. ${ }^{450}$ They may investigate and issue a citation, only to be called out to or notice the property in a similar condition some weeks or months later. Alternatively, the violators may relocate within the jurisdiction and have that property fall back into similar condition. Investigations may on occasion reveal the presence of drug paraphernalia, but they may not necessarily be opioid-related. Moreover, the code enforcement officer may not have grounds for or exercise discretion in involving drug enforcement authorities in the incident.

A host of other financial impacts on cities and counties will be very difficult to quantify. As discussed above in the "easy" category, direct medical costs for local government employees may be identified by insurance billing records. ${ }^{451}$ That said, the Human Resources department may not know whether an employee is using prescription opioids appropriately or is abusing them. If a local government employee is abusing drugs, his productivity almost certainly would be lower, but quantifying that cost to the city or county would be challenging. Moreover, there could be lost productivity due to a family members' addiction, even if the employee himself is clean. In theory, it might be possible to correlate some workplace injuries with prescribed opioids if the worker experiences reduced alertness, focus, or coordination due to the drug. Perhaps the value of damaged equipment, worksite shut-downs, or project delays could be identified. But, again, the process would be laborious. In theory, a city or county Human Resources department could establish a system to track employees prescribed opioids, even appropriately following surgery or for chronic pain, and establish patient education or other interventions. But, again, those would be costly to implement and track.

Lost economic development and opportunities in opioid-impacted communities is another probable effect of opioids that is difficult to quantify. A community may become known for having a high rate of opioid use disorder and thus be passed over by businesses looking to locate new retail stores, manufacturing facilities, or corporate offices. The company's concerns may include suspicion that an insufficient number of

\footnotetext{
450. Telephone Interview with Dennis Bechtold, Hall County Code Enforcement (Aug. 22, 2018).

451. See supra Section IV.B.1.
} 
potential workers could pass a pre-employment drug screen, or that employees, once hired, would be less productive and more expensive to insure than in a different locality. As explained above, lost productivity has been captured on various macro studies of the opioid problem. But those results do not translate clearly to particular localities. The effect of drugs on blight and depressed property values also would be difficult to trace to opioids specifically, much less to quantify.

Lost opportunity costs also would be very difficult to quantify. These opportunity costs relate to services that local government does not offer or provides at a lower level because resources are shifted to address opioid costs. Examples of opportunity costs include police officers having less time to patrol, slower response times from EMS, foregone park maintenance, and non-opioid mental health services.

Other intangible costs, including but not limited to loss of community well-being and safety, both perceived or actual; decreased quality of life and emotional well-being for opioid abusers and their families and social support networks; emotional and economic impacts of overdose deaths on families; and long-term impacts in terms of educational attainment, mental health, employment, and economic self-sufficiency of children from families affected by opioid abuse would all be very difficult to quantify. ${ }^{452}$ In sum, in addition to certain direct costs-including 911, criminal investigations, code enforcement, and Human Resources - that will be harder to quantify than we anticipated, there is a seemingly indeterminate list of indirect and intangible costs of the opioid epidemic that cannot be attributed solely to the drug or easily quantified. Those impacts, however, are real and substantial, warranting local government budget and planning attention.

\section{CONCLUSION}

This article has provided a detailed description of the opioid litigation brought by local governments, which was the genesis for our project. It then surveyed existing studies on the financial impacts of the opioid crisis, noting their shortcomings in terms of quantifying costs for local governments, specifically. Finally, it described our study methodology and findings, noting that local government opioid-related costs fall into three categories, under our rather pedestrian taxonomy - easy, medium,

452. Corwin N. Rhyan, Altarum, The Potential Societal Benefit of Eliminating Opioid Overdoses, Deaths, AND Substance Use Disorders ExceEds \$95 Billion Per YeAr 3 (Nov. 16, 2017), https://altarum.org/sites/default/files/uploaded-publication-files/ResearchBrief_Opioid-Epidemic-Economic-Burden.pdf [https://perma.cc/C45Y-CDFC] (listing various indirect costs). 
and hard, in terms of the ability to quantify them. Our primary takeaway points are: (1) assessing local government plaintiffs' damages in the lawsuits will be very challenging; (2) these challenges stem from the fact that local governments are not set up to provide or track costs on a fee-forservice basis; (3) existing studies of opioid-related costs on localities operate at the macro level and do not support assumptions about microlevel costs actually experienced by any particular city or county; and (4) those studies do not even attempt to include very real indirect and intangible costs, which may not be relevant to the lawsuits but are highly relevant to city and county planning.

Given those points, we conclude by offering a few thoughts about the implications of the current study and our plans for further research and support for local governments in addressing the question of costs related to the opioid epidemic. As noted, our project was designed to inform the local governments plaintiffs' damages claims as well as local governments' decision-making regarding policy choices and resource allocation to address the opioid crisis in their communities. With respect to the litigation, local government plaintiffs and the MDL and other courts will need to more precisely identify truly local, as opposed to federal, state, school, hospital authority, or private costs. A number of alleged damages, especially medical costs, will fall only minimally or indirectly on cities and counties. Even for the "easy" category of costs, local government plaintiffs will need to expend resources to respond to the MDL discovery for ten years worth of information. For the "medium" category of costs, cities and counties may be able to capture some of those costs with additional tracking systems, templates, feedback loops, or coding systems. One of our future plans for this project would be to work with select Georgia local governments - not necessarily the same ones interviewed for this study - to pilot those sorts of instruments and training modules. As noted above, local government recordkeeping and accounting is often rudimentary, especially in rural communities hit especially hard by the epidemic. Thus, any assistance would likely be welcome. Local governments will have to weigh the costs of expending resources to better track opioids costs against the benefits from a litigation settlement and other funding and planning aims. For the "hard" category of cases, even more resource-intensive tracking systems could be developed for the direct costs, including 911, police effort, and Human Resources. For the indirect and intangible costs, local governments may simply want to be aware of those as they make budget and other resource allocation decisions.

This study was limited in scope and largely anecdotal in responses collected. For further research, we would like to expand and formalize the 
survey to additional local governments in Georgia, drilling down more precisely on the available data in those communities. Additionally, comparative research of cities and counties in other parts of the country would be informative, especially given that many of the costs we excluded - child welfare, public health, and medical treatment costsmight fall more directly on local governments in other states. Other potential costs that we identified, such as solid waste and economic development, may have become apparent in other parts of the country. Comparing local governments with similar demographics (e.g., rural or urban, high opioid overdose rates, MAT or other evidence-based treatment in jails or treatment centers) also would be instructive. By all accounts, the direct, indirect, and intangible impact of the opioid epidemic continues to accumulate across the country. This preliminary study, informed by interviews with three Georgia cities and counties, provides a realistic assessment of local governments' ability to accurately and fully quantify the toll the epidemic has taken on their communities. 